\title{
Pseudomonas syringae pv. tomato DC3000 Type III Effector HopAA1-1 Functions Redundantly with Chlorosis-Promoting Factor PSPTO4723 to Produce Bacterial Speck Lesions in Host Tomato
}

\author{
Kathy R. Munkvold, Alistair B. Russell, Brian H. Kvitko, and Alan Collmer \\ Department of Plant Pathology and Plant-Microbe Biology, Cornell University, Ithaca NY 14853, U.S.A.
}

Submitted 11 March 2009. Accepted 22 June 2009.

\begin{abstract}
The ability of Pseudomonas syringae pv. tomato DC3000 to cause bacterial speck disease in tomato is dependent on the injection, via the type III secretion system, of approximately $28 \mathrm{Avr} / \mathrm{Hop}$ effector proteins. HopAA1-1 is encoded in the conserved effector locus (CEL) of the P. syringae Hrp pathogenicity island. Transiently expressed HopAA1-1 acts inside Saccharomyces cerevisiae and plant cells to elicit cell death. hopAA1 homologs were cloned and sequenced from the CEL of seven $P$. syringae strains representing diverse pathovars. Analysis of the sequences revealed that HopAA1-1 carries a potential GTPase-activating protein (GAP) domain, GALRA, which is polymorphic (FEN instead of LRA) in HopAA1-2, a paralogous DC3000 effector. Deleting hopAA1-1 from DC3000 reduces the formation of necrotic speck lesions in dip-inoculated tomato leaves if effector-gene cluster IX or just PSPTO4723 within this region has been deleted. A HopAA1-1 mutant in which the putative catalytic arginine in the GAP-like domain has been replaced with alanine retains its ability to kill yeast and promote the formation of speck lesions by the $\triangle$ hopAA1-1 $\triangle \mathrm{IX}$ mutant, but a HopAA1-1 mutant carrying the FEN polymorphism loses both of these abilities. Unexpectedly, PSPTO4723 does not appear to encode an effector and its deletion also reduces disease-associated chlorosis.
\end{abstract}

Pseudomonas syringae pv. tomato DC3000 is a pathogen of tomato and Arabidopsis that has become a model for functional genomics and the study of plant-pathogen interactions (Buell et al. 2003; Lindeberg et al. 2008). DC3000 virulence is dependent upon the injection by the type III secretion system (T3SS) of approximately 28 effector proteins that collectively suppress defenses and promote bacterial growth and the production of 'bacterial speck' disease lesions in hosts (Chang et al. 2005; Kvitko et al. 2009; Lindeberg et al. 2006; Schechter et al. 2006). Although there has been exciting progress in identifying the activities and targets of several $P$. syringae effectors inside plant cells, the functions of most of the DC3000 effectors await elucidation (Block et al. 2008; Cunnac et al. 2009; Gohre and Robatzek 2008). Common obstacles to the study of $P$ syringae effectors include the lack of any biological phenotype following mutation or heterologous expression of the respective genes and the lack of clues to biochemical activity.

K. R. Munkvold and A. B. Russell contributed equally to this study.

Corresponding author: Alan Collmer; Telephone: +1.607.255.7843; Fax: +1.607.255.4471; E-mail: arc2@ cornell.edu
One approach we have taken to these problems is to comprehensively identify the subset of DC3000 effectors that are toxic when expressed in the model eukaryote Saccharomyces cerevisiae (Munkvold et al. 2008). Another approach is to construct combinatorial deletions in DC3000 effector genes to eliminate redundant effector groups and produce stronger phenotypes for single effector genes in virulence tests (Kvitko et al. 2009; Wei et al. 2007). The HopAA1 effector family is of particular interest to us because the encoding genes are present in diverse pathovars of $P$. syringae (Alfano et al. 2000; Badel et al. 2002), and HopAA1-1 is one of seven DC3000 effectors that are toxic when expressed in yeast cells (Munkvold et al. 2008). Furthermore, hopAA1-1 also induces cell death when expressed within plant cells (Munkvold et al. 2008). However, hopAAl mutations in $P$. syringae reported to date have only subtle phenotypes (Badel et al. 2002; Vinatzer et al. 2006), and we have no clue to the biochemical activity of this effector family.

HopAA1-1 is considered to be among the ancient $P$. syringae effectors that were acquired before the radiation of $P$. syringae into the current pathovars (Rohmer et al. 2004), and this concept is supported by the location of the hopAAl gene in the conserved effector locus (CEL), which is part of the tripartite Hrp pathogenicity island that also carries the $h r p / h r c$ (hypersensitive response and pathogenicity/conserved) genes encoding the T3SS (Alfano et al. 2000). The DC3000 gene is denoted hopAA1-1 because it has a paralog, hopAA1-2, in a cluster of four effector genes ('cluster IX') that is located elsewhere in the genome (Badel et al. 2002; Wei et al. 2007). The DC3000 gene will sometimes be denoted hopAAl-1 $l_{\mathrm{Pto} \text { DC3000 }}$ in this report for clarity when being compared with hopAAl genes from other $P$. syringae pathovars (Lindeberg et al. 2005).

Most of the $P$. syringae pathovars fall into three major phylogroups based on phylogenetic analyses (Sarkar and Guttman 2004; Sawada et al. 1999). Strains in pathovars representing each of these major phylogroups have been sequenced. These are $P$. syringae pv. tomato DC3000 (group 1) (Buell et al. 2003), P. syringae pv. syringae B728a (group 2) (Feil et al. 2005), and $P$. syringae pv. phaseolicola 1448A (group 3) (Joardar et al. 2005). The CEL in each of these sequenced strains carries three effector genes-avrE, hopM1, and hopAAl-although hopMl and hopAAl appear nonfunctional in 1448A (Lindeberg et al. 2006). The DC3000 CEL contains a fourth effector gene, hopN1 (López-Solanilla et al. 2004).

Among the CEL effectors, the AvrE effector family is the most widespread among plant pathogenic bacteria and appears universal to pathogens with the Hrp1 class of T3SS (plant pathogens in the Pseudomonadaceae and Enterobacteriaceae) 
(Bogdanove et al. 1998b; Cornelis 2006; Ham et al. 2006). Mutation of $d s p A / E$, the $a v r E$ homolog in Erwinia amylovora, leads to a complete loss of pathogenicity (Bogdanove et al. 1998a; Gaudriault et al. 1997).

The DC3000 AvrE and HopM1 effectors have been studied extensively (Badel et al. 2003, 2006; DebRoy et al. 2004; Nomura et al. 2006). Deletion of the DC3000 CEL region carrying avrE, hopM1, and hopAA1-1 results in a loss of virulence (Alfano et al. 2000). Virulence can be restored by expression in trans of either AvrE or HopM1 but not by HopAA1-1 (DebRoy et al. 2004). Evidence for a strong virulence function in plants for HopAA1 family members is lacking, although previous work has shown that mutation of both hopAAl-1 and hopAA1-2 in DC3000 produces the subtle phenotype of an increased frequency of small colonies in Arabidopsis without an associated decrease in symptom development or bacterial multiplication in planta (Badel et al. 2002).

To further characterize the HopAA1 effector family, we cloned and sequenced the hopAAl homologs from seven different pathovars of $P$. syringae and determined the effects of expressing these genes in yeast, thus revealing the apparent inactivity of many phylogroup 3 hopAAl genes. We exploited the multiple hopAAl sequences to discern a putative GTPaseactivating protein (GAP) domain in these proteins, which was represented by three strongly divergent amino acids in HopAA1-2. Introduction of this GAP domain polymorphism into HopAA1-1 abolished the ability of HopAA1-1 to inhibit yeast growth. In search of a more useful virulence phenotype for hopAA1-1 mutations, we discovered that a mutant deleted for both hopAA1-1 and effector-gene cluster IX was significantly reduced in the number of bacterial speck lesions it produced in dip-inoculated tomato leaves. Importantly, the virulence defect could be restored by expression in trans of native hopAAl-1 but not by hopAAl-1 carrying the hopAAl-2 GAP domain polymorphism or any other hopAA1-1 derivative that had lost the ability to inhibit yeast growth. We noted that deletion of cluster IX also reduced the diffuse chlorosis in tomato leaves that accompanies DC3000 infections. Surprisingly, deletion of PSPT04723, one of two open reading frames (ORF) within cluster IX encoding hypothetical proteins with no properties of type III effectors, also reduced diffuse chlorosis and reduced lesion numbers if hopAAl-1 was deleted.

\section{RESULTS}

hopAA1 family members cloned from representative $P$. syringae strains reveal the prevalence of a truncated form in the pathovar phylogroup containing $P$. syringae pv. phaseolicola.

To find regions of conserved amino-acid sequence within the HopAA1 family that might provide a clue to the molecular

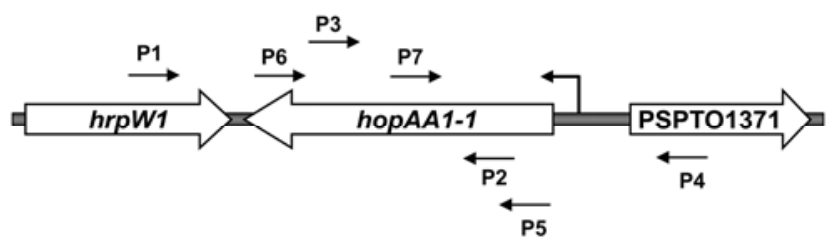

Fig. 1. Strategy for cloning hopAAl family members from Pseudomonas syringae pathovars. The diagram depicts the genomic region of $P$. syringae pv. tomato DC3000 that contains hrpW1, hopAA1-1, and PSPTO1371. Primer sets P1 and P2 and P3 and P4 were used to amplify regions containing hopAAl and flanking sequences. Primer sets P5 and P6 and P5 and P7 correspond to the predicted start and stop codons of the newly sequenced hopAA1 family members. The bent arrow designates the location and direction of the hopAA1-1 Pto DC3000 native promoter. function of HopAA1-1, we cloned seven hopAAl family members from different pathovars of $P$. syringae that were selected based on the presence of hopAAl-like sequences observed via Southern hybridization (Badel et al. 2002). The cloning strategy employed the targeting of sequences within and flanking hopAAl in the CEL of each pathovar (Fig. 1). Therefore, the potential presence of hopAAl-like sequences outside this region of the genome, for example, hopAA1-2 2 to DC3000, was not addressed in this work. A primer set corresponding to conserved regions of $h r p W l$ and hopAAl was used to amplify the $3^{\prime}$ region of hopAAl-like sequences. Another primer set was designed to conserved regions of hopAAl and PSPTO1371 for amplification of the $5^{\prime}$ region of hopAAl-like sequences (Alfano et al. 2000). Upon determining the sequence of these regions, primers were designed to amplify the full-length hopAAl sequence from each pathovar. Amplification products were cloned and consensus sequences were derived from sequencing data of three independent clones.

hopAAl homologs from $P$. syringae pvs. tabaci and angulata were found to be $100 \%$ identical (Fig. 2), and in subsequent work, we used only hopAA $1_{\mathrm{Pta}}$. Another highly similar pair of homologs that share $99 \%$ identity comes from $P$. syringae pvs. glycinea and phaseolicola. These pathovars are closely related and have been shown to cluster together in a phylogenic study of $P$. syringae pathovars based on the core genome (Sarkar and Guttman 2004). A third set of closely related hopAAl homologs ( $99 \%$ identical) includes those from strains T1 and DC3000, both of $P$. syringae pv. tomato. A recent, next-generation sequencing analysis of the T1 genome provides an independent and identical sequence of the $\mathrm{T} 1$ hopAAl gene (Almeida et al. 2009).

The observation that similarity among particular hopAAl family members was correlated with overall pathovar relatedness provoked an investigation of whether this finding held true for the entire hopAAl family. Using CLUSTAL X (Thompson et al. 1997), the DNA sequences of the newly identified hopAAl family members were aligned along with six other hopAAl-like sequences already present in GenBank. The topology of the phylogenic tree generated from hopAAl family sequences (Fig. 2) was similar to the topology of the phylogenetic tree for the core genome of $P$. syringae (Sarkar and Guttman 2004). This result supports previous evidence that hopAAl is among the ancient and stably maintained effector genes in $P$. syringae (Rohmer et al. 2004). Therefore, it is likely that $P$. syringae acquired hopAAl prior to the diversification of different pathovars, which is also consistent with its presence in the CEL (Alfano et al. 2000). Interestingly, the hopAAl homologs from $P$. syringae pvs. tabaci, angulata, phaseolicola, and glycinea contain a frameshift leading to a premature stop codon directly after codon 189 (Fig. 2). The frameshift occurs due to a single insertion of an A after position 562 of the DNA sequence. However, hopAA $l_{\mathrm{Pta}}$ does possess a start codon and is predicted to encode a truncated form of HopAA1. Thus, with the exception of hop $A A l_{\mathrm{Pla}}$, all of the hopAAl genes in members of $P$. syringae phylogroup 3 are either truncated, not expressed, or both.

A consensus sequence that was generated by CLUSTAL $\mathrm{X}$ multiple alignment of the predicted amino-acid sequences for all HopAA1 family members was used in several bioinformatic analyses. As for many effectors, BLAST, InterProScan, SMART, and Phyre did not return significant hits to proteins of known function for the HopAA1 consensus sequence (data not shown).

\section{All full-length HopAA1 homologs inhibit the growth of yeast.}

Our previous work on HopAA1- $1_{\text {Pto DC3000 }}$ showed that expression of this effector in yeast leads to the strong gain-of- 
function phenotype of cell death (Munkvold et al. 2008). Therefore, we tested the ability of each HopAA1 homolog to inhibit the growth of yeast. Expression of homologs that were predicted to encode a full-length protein resulted in strong growth inhibition in yeast (Fig. 3). In contrast, expression of hopAAl $1_{\mathrm{Pta}}$, which is predicted to encode a truncated form of the protein, did not affect yeast growth, although immunoblot analysis confirmed that the predicted protein was produced in yeast (data not shown). This observation provides further support of the finding that deletion of 100 or more amino acids from the $\mathrm{C}$ terminus of HopAA1- $1_{\text {Pto DC3000 }}$ abolishes growth-inhibiting activity in yeast (Munkvold et al. 2008).

\section{A putative GTPase activation domain is located}

in the $\mathrm{N}$-proximal region of HopAA1-1 Pto DC3000 and homologs from other $P$. syringae strains

but is significantly polymorphic in HopAA1-2 ${ }_{\text {Pto DC3000. }}$.

Examination of the less significant hits obtained from our Phyre analysis revealed weak similarity to the N-terminal domain of the $P$. aeruginosa effector ExoS. ExoS has a bipartite structure in which the N-terminal domain functions as a GAP for Rho GTPases and the C-terminal domain has ADP-ribosyltranferase activity (Goehring et al. 1999). GAP activity has been observed in effectors from animal pathogenic bacteria. For example, the Yersinia effector YopE and the Salmonella effector SptP both possess GAP activity (Fu and Galán 1999; Von Pawel-Rammingen et al. 2000). Alignment of the

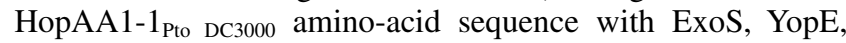

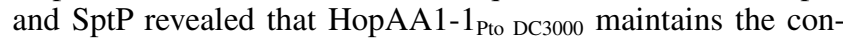
served arginine finger motif required for GAP activity (Fig. 4A) (Scheffzek et al. 1997).

Because HopAA $1_{\text {Pto DC3000 }}$ is conserved among strains of $P$. syringae, we wondered if the putative GAP domain was present in all HopAA1 family members. Alignment of all known HopAA1 homologs from $P$. syringae revealed that the conserved arginine was present in all HopAA1 family members

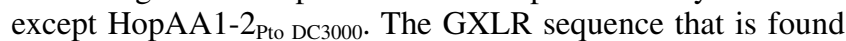
in all bacterial effectors with GAP activity is present only in the strains from $P$. syringae phylogroup 1, i.e., HopAA1- $1_{\mathrm{Pto}}$ DC3000, HopAA $1_{\text {Pto T1 }}$, and HopAA $1_{\text {Pma ES4326 }}$ (Fig. 4B). In contrast, the glycine in this region was replaced with a threonine in phylogroup 2 and a serine in phylogroup 3 .

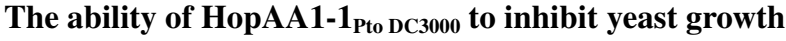
is unaffected by site-directed mutation of the putative GAP domain catalytic arginine but is diminished by substitution

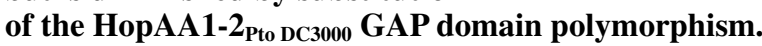

To test whether HopAA1- $1_{\text {Pto DC } 3000}-$ associated growth inhibition in yeast required the putative GAP activity, the conserved arginine at amino acid 121 was changed to alanine by site-directed mutagenesis to produce HopAA $1-1_{\mathrm{R} 121 \mathrm{~A}}$. As expected (Munkvold et al. 2008), HopAA1-2 2 to DC3000 did not inhibit yeast growth (Fig. 4C). Therefore, we also constructed a mutant of HopAA1-1 that carried the sequence of

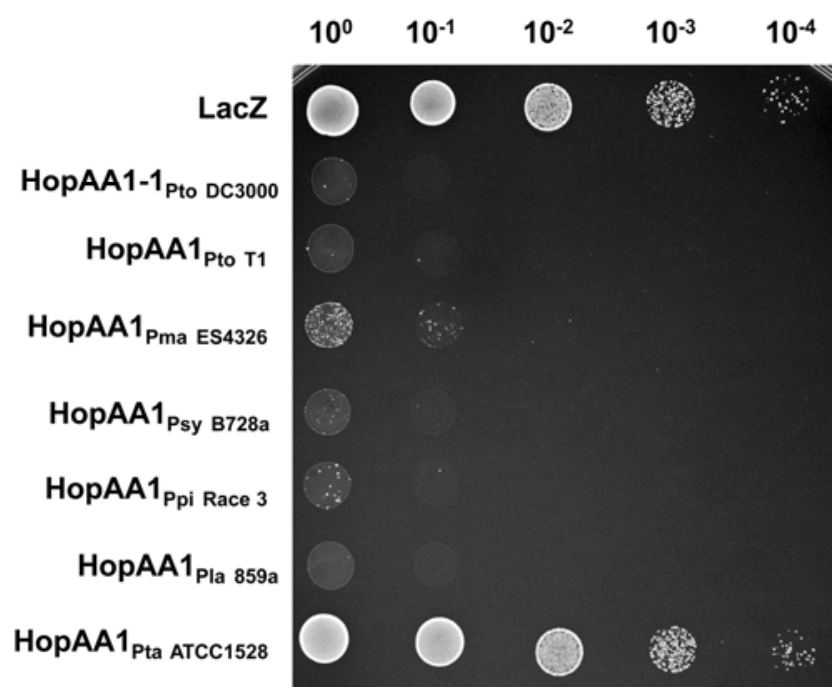

Fig. 3. Expression in yeast of HopAA1 family members that are not truncated results in inhibition of growth. Yeast strains (BY4741a) harboring the high-copy plasmid pYES-DEST52 encoding LacZ as a control or HopAA1 family members with a C-terminal V5-epitope tag were grown overnight in selective, noninducing, raffinose media. The cultures were normalized to an optical density at $600 \mathrm{~nm}$ of 0.45 , and serial 10 -fold dilutions were spotted onto selective media containing galactose to induce the expression of the protein. Photographs were taken after 2 days of incubation. Pto $=$ P. syringae pv. tomato $;$ Pma $=P$. syringae pv. maculicola $;$ Psy $=P$. syringae pv. syringae; $\mathrm{Ppi}=P$. syringae pv. pisi; $\mathrm{Pla}=$ P. syringae $\mathrm{pv}$. lachrymans $; \mathrm{Pta}=P$. syringae pv. tabaci .

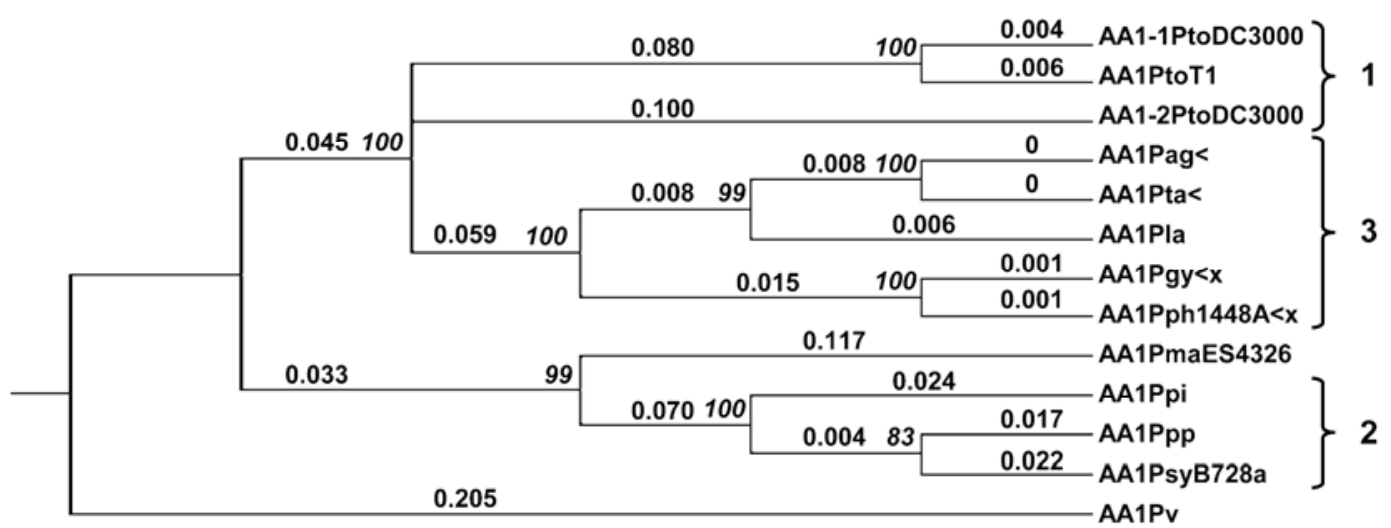

Fig. 2. Comparisons of DNA and predicted amino-acid sequences for hopAAl family members. Multiple-sequence alignment was performed for hopAA1 family member DNA sequences using the CLUSTAL X method (Thompson et al. 1997). All hopAA1 sequences aligned were equivalent in length to hopAA1-1 $1_{\text {Pto } D C 3000}$. A neighbor-joining tree was constructed using PAUP* 4.0, rooted with hopAA1 $1_{\mathrm{Pv}}$ as a monophyletic outgroup, and was visualized with TreeViewX version 0.5.0. Nucleotide substitution rates are indicated as substitutions per site in bold along the branches, and bootstrap values (designated in percentages) are displayed in gray italics at branch nodes. Numbers next to braces (far right) indicate the phylogroup as determined for the Pseudomonas syringae core genome within which each strain clusters (Sarkar and Guttman 2004). HopAA1 proteins that are truncated to 189 amino acids are denoted with ' $<$ ', and those without a start codon, as compared with the hopAA1-1 Pto DC3000 sequence, are denoted with ' $\mathrm{x}$ '. Pto $=P$. syringae pv. tomato $; \mathrm{Pag}=P$. syringae pv. angulata $; \mathrm{Pta}=P$. syringae pv. tabaci $; \mathrm{Pla}=P$. syringae pv. lachrymans; Pgy $=$ P. syringae pv. glycinea $;$ Pph $=$ P. syringae pv. phaseolicola $; \mathrm{Pma}=P$. syringae pv. maculicola $; \mathrm{Ppi}=P$. syringae pv. pisi $; \mathrm{Ppp}=P$. syringae pv. papulans $; \mathrm{Psy}=P$. syringae pv. syringae. $\mathrm{Pv}=$ $P$. viridiflava. 
HopAA1-2 in this region (HopAA1-1 $1_{\text {LRA-FEN }}$ ). The HopAA11 mutants were expressed in yeast and were assayed for their ability to inhibit growth. The single arginine to alanine substitution did not alleviate growth inhibition induced by HopAA1-1 in yeast (Fig. 4C). However, the mutation of amino acids 120 to 122 from LRA to FEN did alleviate most of the growth inhibition associated with HopAA1-1 $1_{\text {Pto DC3000 }}$ expression in yeast (Fig. 4C). Immunoblot analysis confirmed that the HopAA1-1 LRA-FEN protein was produced in yeast (Fig. 4D). Thus, the polymorphism in this region of

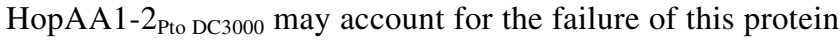
to inhibit yeast growth.

Analysis of $P$. syringae pv. tomato DC3000 mutants reveals that HopAA1-1 significantly contributes to lesion formation in host tomato when DC3000 derivatives lacking effector-gene cluster IX are inoculated by dipping.

To facilitate exploration of any activity of HopAA1-1 in promoting DC3000 virulence in tomato, we sought conditions that would yield a workable virulence phenotype for

A

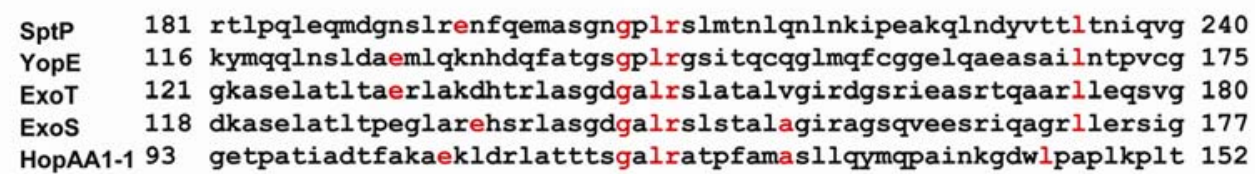

\begin{tabular}{|c|c|c|c|c|c|c|c|}
\hline HopAA1-1PtoDC 3000 & 93 & GETPATIADTEAKI & KLDRLATTTS & GALRA & TPEAN & LLQYMQPAINKGDV & APPLPL \\
\hline HopAA $1-2$ PtoDC 3000 & 93 & GETPATIAETEAK & KEDRLATTAS & SAFEN & FPEAA & SVLQYMQPAINKGDV & ATPLKPL \\
\hline HopAA1PtoT 1 & 93 & GETPATIADTFAK & KLDRLATTAS & GALRA & APEAN & LLQYMQPAINKGDV & 'APLKPL' \\
\hline HopAA 1PmaES 4326 & 91 & GETALSIGETEAKA & KEDRMASAAS & GALRA & FPEAA & VLQYMQPAINKGDV & TPLKPL. \\
\hline HopAA1Pag & 93 & GETPLSIGETFAKA & KEDRLATTAS & SALRA & FPEAA & VLQYMQPGINKGDV & PAPLKPL' \\
\hline HopAA1Pta & 93 & GETPLSIGETFAKA & KEDRLATTAS & SALRA & FPEAA & VLQYMQPGINKGDV & 'APLKPL' \\
\hline HopAA1Pgy & 96 & GEPRASIGETEAK & KEDRLATTAS & SALRA & FPEAA & SVLQYMQPAINKGDV & PAPLKPL' \\
\hline HopAA1Pla & 93 & GETPLSIGETEAKA & KEDRLATTAS & SALRA & CPEAA & SVLQYMQPA INKGDV & PAPLKPL' \\
\hline HopAA1Pph1448A & 96 & GEPRASIGETEAKA & KEDRLATTAS & SALRA & CPEAA & SVLQYMQPAINKGDV & 'APLKPL' \\
\hline HopAA1Ppi & 94 & GETPATIADTFAKA & KEDRMATTAS & FALRA & FPFAA & VLLQYMQPAINKGDV & TPLKPL' \\
\hline HopAA1Ppp & 92 & RETPATIADTEAK & KEDRMATTAS & FALRA & FPVAA & VVLQYMQPAINKGDV & 'TPLKPL \\
\hline HopAA1PsyB 728a & 92 & GETPATIADTEAKA & KEDRMATTAS & ITLRA & FPEA & VLQYMQPA INKGDV & PMPLKPL' \\
\hline
\end{tabular}

C

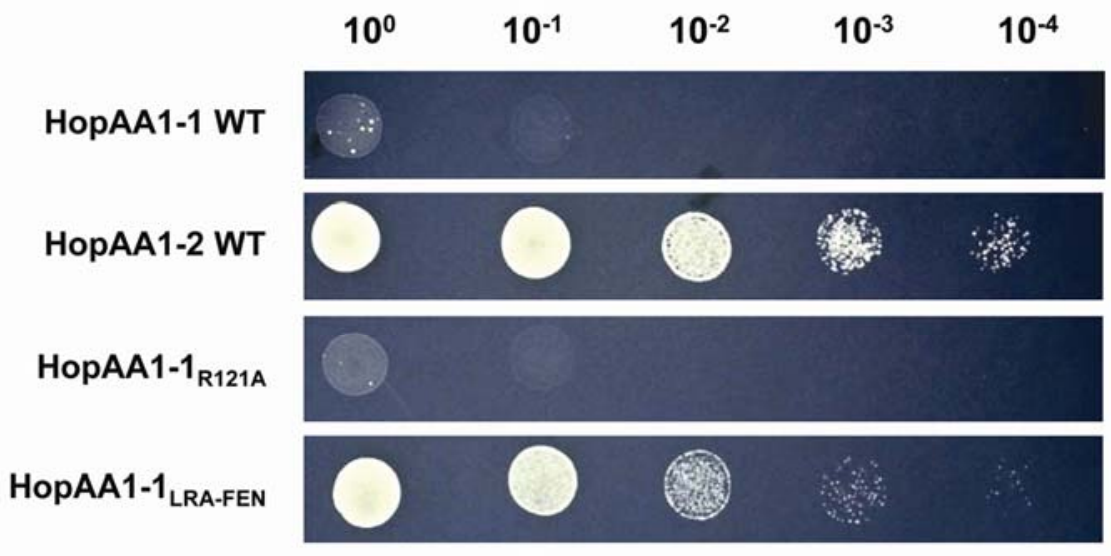

D

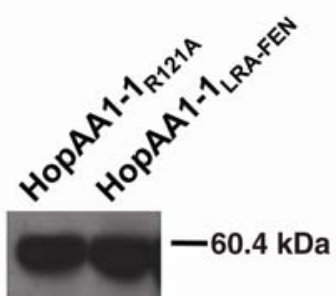

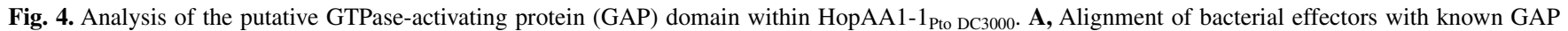

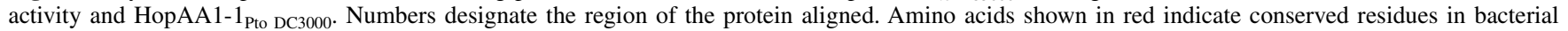
effectors with GAP activity. The underlined residues show the location of the arginine finger motif. B, Alignment of HopAA1 family members using AlignX within the Vector NTI software suite. Boxed regions indicate the conserved residues shown in red in A. Black arrow indicates R121. Pto $=P$. syringae pv. tomato $;$ Pma $=P$. syringae pv. maculicola $; \mathrm{Pag}=P$. syringae pv. angulata $; \mathrm{Pta}=P$. syringae pv. tabaci $;$ Pgy $=$ P. syringae pv. glycinea $;$ Pla $=$ P. syringae pv. lachrymans $; \mathrm{Pph}=$ P. syringae pv. phaseolicola $; \mathrm{Ppi}=P$. syringae pv. pisi $; \mathrm{Ppp}=P$. syringae pv. papulans, Psy $=$ P. syringae pv. syringae. $\mathrm{C}, \mathrm{HopAA} 1-1_{\mathrm{Pto}}$

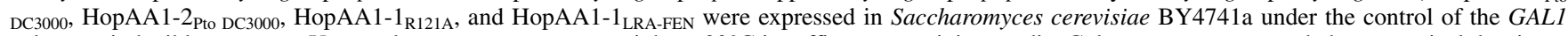
galactose-inducible promoter. Yeast cultures were grown overnight at $30^{\circ} \mathrm{C}$ in raffinose-containing media. Cultures were resuspended to an optical density at $600 \mathrm{~nm}$ of 0.45 , were serially diluted 10 -fold in raffinose media, and were spotted onto galactose-containing media to induce expression of the protein. Photographs were taken after 2 days of incubation. D, Immunoblot analysis using anti-V5 antibody to detect expression of HopAA1- $1_{\mathrm{R} 121 \mathrm{~A}}-\mathrm{V} 5$ and HopAA1-1 LRA-FEN V 5 fusion proteins after induction for $3 \mathrm{~h}$ in galactose-containing media. Predicted protein size is $55.7 \mathrm{kDa}$ for both fusion proteins. 
hopAA1-1 mutations. The variables we addressed were genetic background (particularly composition of the effector repertoire), method of inoculation, and phenotype measured. We had previously observed an increase in the number of small ('failed') colonies relative to wild-type DC3000 when a green fluorescent protein-labeled hopAA1-1::nptII/hopAA1-2::aadA1 double mutant was infiltrated with a blunt syringe into Arabidopsis leaves (Badel et al. 2002). However, this mutant and inoculation method did not reveal any defect in the final growth or symptom production in Arabidopsis or tomato, and assays involving confocal microscopy are time consuming.

To facilitate future construction of unmarked combinatorial mutants, we used pK18mobsacB to construct a complete deletion of the hopAA1-1 ORF, with the spectinomycin-resistance cassette marking the deletion flanked by FRT sites, as previously described (Wei et al. 2007). We also exploited previously constructed intermediates for marker-exchange mutagenesis (Wei et al. 2007) to construct combinatorial deletions involving hopAA1-1 and effector-gene cluster IX, which includes hopAA1-2. Dip-inoculation of the leaves of whole tomato plants with these mutants enabled us to observe significant differences in the numbers and appearance of the resulting speck lesions.
Although we observed no major difference in the number of necrotic specks produced by DC3000 and the $\triangle \mathrm{IX}$ or $\triangle$ hopAA1-1 mutants, the $\triangle \mathrm{IX} \triangle h o p A A 1-1$ double mutant was strongly reduced in lesion formation, typically producing only $1 / 3$ the number of necrotic specks per plant (Fig. 5A and B). The $\Delta \mathrm{IX}$ mutant was interestingly altered in its virulence rela-

Table 1. Competitive index assays of bacterial growth in tomato leaves and in culture

\begin{tabular}{llll}
\hline & \multicolumn{3}{c}{ Competitive index } \\
\cline { 2 - 4 } Strains & $\begin{array}{c}\text { Blunt-syringe } \\
\text { inoculation }^{\mathbf{a}}\end{array}$ & \multicolumn{1}{c}{$\begin{array}{c}\text { Dip } \\
\text { inoculation }^{\mathbf{b}}\end{array}$} & $\begin{array}{l}\text { King's B } \\
\text { medium }^{\mathbf{c}}\end{array}$ \\
\hline DC3000 vs. $\Delta h o p A A 1-1$ & $1.14 \pm 0.45$ & $\mathrm{ND}$ & $\mathrm{ND}$ \\
$\Delta \mathrm{IX}$ vs. $\Delta \mathrm{IX} \Delta h o p A A 1-1$ & $0.71 \pm 0.24$ & $0.75 \pm 0.53$ & $0.95 \pm 0.23$ \\
\hline
\end{tabular}

${ }^{\text {a }}$ Leaves were sampled at 3 days postinoculation (dpi); data represent mean and standard deviation (SD) for four samples from each of two plants in three independent experiments.

${ }^{\mathrm{b}}$ Leaves were sampled at $5 \mathrm{dpi}$; data represent mean and SD for four samples from each of two plants in three independent experiments.

${ }^{c}$ Bacterial populations were determined in cultures grown overnight; data represent mean and SD for three samples from each of three independent experiments.
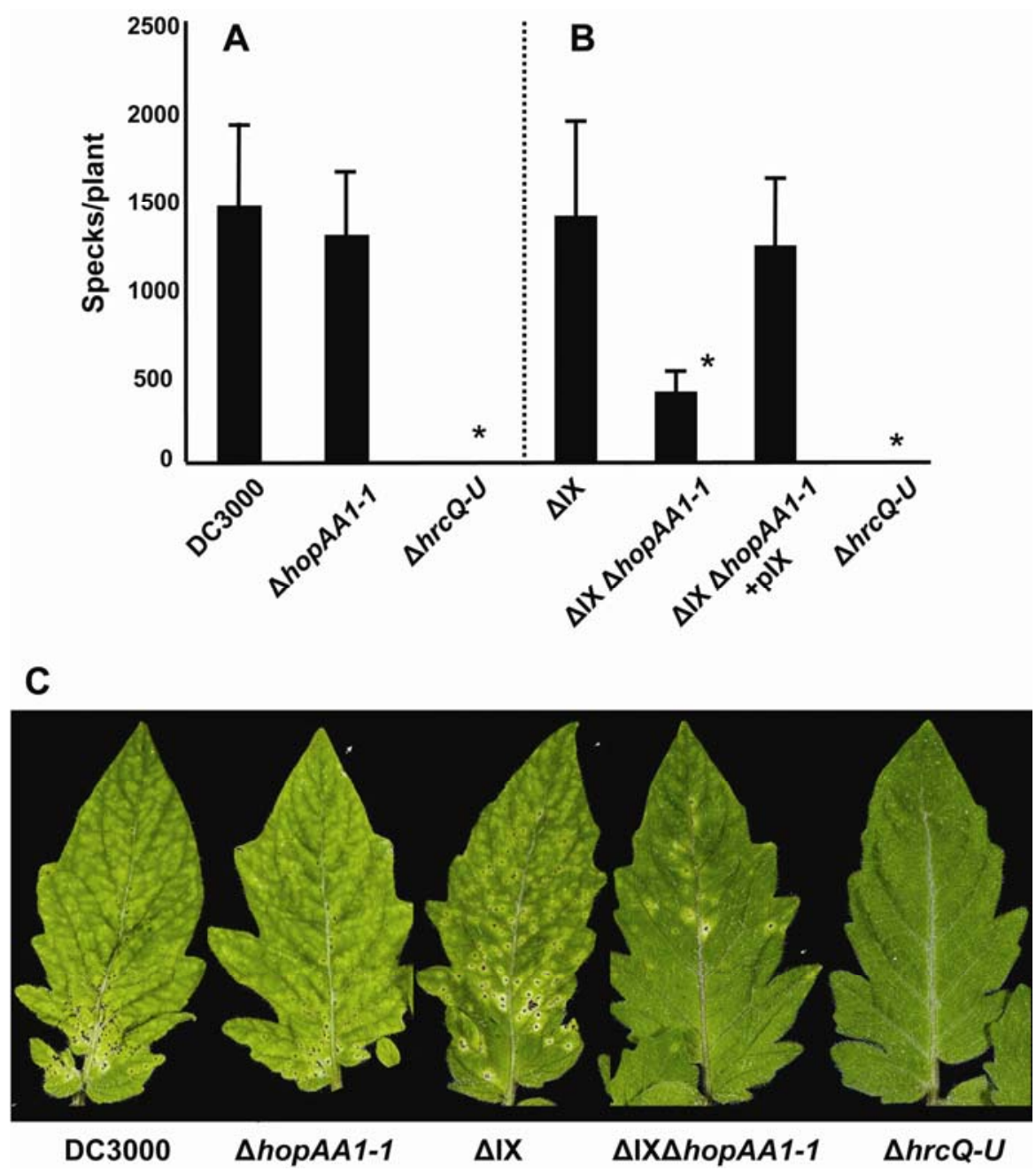

Fig. 5. Dip-inoculated Pseudomonas syringae pv. tomato DC3000 mutants lacking hopAA1-1 and effector-gene cluster IX have a reduced ability to produce lesions in host tomato leaves. A and $\mathbf{B}$, Tomato plants were inoculated by dipping in inoculum containing the indicated strains at $1 \times 10^{5} \mathrm{CFU} / \mathrm{ml}$, and the numbers of lesions on entire plants were counted 5 days later. The dotted line separates two sets of independent experiments. Data represent the mean and standard deviation for six samples involving two plants in three independent experiments. Values marked with an asterisk are significantly different $(P<$ 0.01) from DC3000 (A) or the $\triangle \mathrm{IX}$ mutant (B) based on Student's $t$-test. C, Photographs show characteristic differences in symptoms produced in tomato leaves by DC3000, $\triangle h o p A A 1-1, \Delta \mathrm{IX}, \triangle \mathrm{IX} \Delta h o p A A 1-1$, and $\Delta h r c Q-U$ (type III secretion system-minus CUCPB5113) mutants 5 days after inoculation as above. 
tive to wild-type DC3000, in that chlorosis was more focused around speck lesions (Fig. 5C). Consequently, the $\Delta \mathrm{IX}$ mutant infection produced leaves that are comparatively greener overall, and the speck-associated chlorotic halos show more contrast against this background. The symptoms produced by the $\triangle \mathrm{IX} \triangle$ hopAA1-1 mutant also have this appearance of reduced diffuse chlorosis (Fig. 5C).

To address the possibility that the $\triangle \mathrm{IX} \Delta$ hopAAl-1 mutant produced fewer speck lesions because of a mutation elsewhere in the DC3000 genome, we used recombination in yeast to assemble, from two polymerase chain reaction (PCR)-cloned DNA fragments, the entire cluster IX region in broad-host range vector pCPP5296. The introduction of this plasmid, pCPP5957, into the $\triangle \mathrm{IX} \Delta h o p A A 1-1$ mutant restored parental levels of speck production (Fig. $5 \mathrm{~B}$ ). To determine whether the $\triangle h o p A A 1-1$ or $\triangle \mathrm{IX} \triangle h o p A A 1-1$ mutants were reduced in their ability to grow in tomato, we used highly sensitive, competitive index assays (Macho et al. 2007). Interestingly, we did not detect a significant reduction in growth of the $\triangle \mathrm{IX} \triangle$ hopAA1-1 mutant in tissue coinoculated with its $\triangle \mathrm{IX}$ parent, when inoculated by either infiltration or dipping (Table 1). Thus, HopAA1-1 has an important role in enabling a $\Delta \mathrm{IX}$ mutant to produce lesions, but it appears less important in enabling the $\Delta \mathrm{IX}$ mutant to grow in tomato leaves.
Wild-type hopAA1-1 Pto DC3000 $_{\text {expressed in trans }}$ can promote virulence in the $\triangle \mathrm{IX} \Delta h o p A A 1-1$ mutant, but hopAA1-2 and all hopAA1-1 Pto DC3000 $_{\text {mutants }}$ that have lost the ability to inhibit yeast fail to promote virulence.

To determine if the loss of hopAA1-2 (as a consequence of deleting effector cluster IX) was responsible for the reduced ability of the $\triangle \mathrm{IX} \triangle h o p A A 1-1$ double mutant to produce speck lesions, we tested the previously constructed hopAA1-1::nptII/ hopAA1-2::aadA1 double mutant for its ability to produce lesions in dip-inoculated tomato. The lesion counts produced by this mutant were not significantly reduced relative to the $\Delta \mathrm{IX}$ mutant, whereas, as expected from results shown in Figure 5, lesion counts produced by the $\triangle \mathrm{IX} \triangle$ hopAA1-1 mutant were significantly lower (Fig. 6A). To determine the ability of HopAA1 variants to promote lesion formation by the $\triangle \mathrm{IX} \Delta$ hopAA1-1 mutant, we expressed these proteins with $\mathrm{C}$ terminal hemagglutinin (HA) tags from HrpL-responsive promoters in pCPP5372. Immunoblot analysis confirmed that most of the proteins were produced at the same levels as HopAA1-1 (Fig. 6B). However, HopAA1-2 accumulation was weak and, therefore, we could not meaningfully test the ability of HopAA1-2 to complement the $\triangle \mathrm{IX} \Delta$ hopAAl-1 mutant in the experiment shown in Figure 6A. Nevertheless, the wild-type
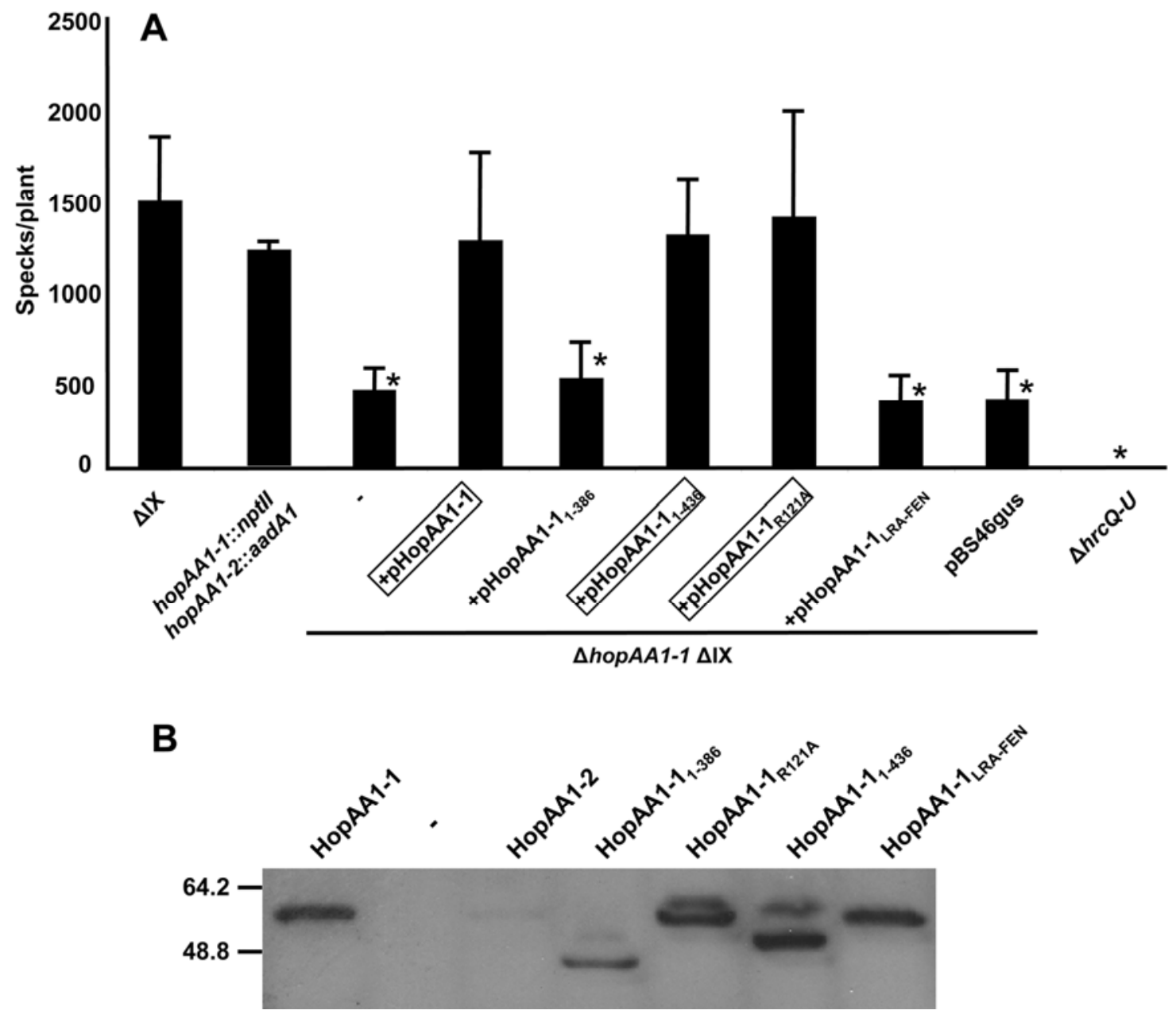

Fig. 6. Wild-type HopAA1-1 $1_{\text {Pto DC3000 }}$ expressed in trans can restore lesion formation activity to the $\triangle \mathrm{IX} \triangle$ hopAA1-1 mutant, but HopAA1-2 and all HopAA1$1_{\text {Pto DC3000 }}$ mutants that have lost the ability to inhibit yeast growth fail to restore bacterial virulence. A, Tomato leaves were inoculated by dipping and the numbers of resulting lesions per plant were determined. Values marked with an asterisk are significantly different $(P<0.01)$ from the $\Delta \mathrm{IX}$ mutant based on Student's $t$-test. HopAA1 variants were expressed from HrpL-responsive promoters and produced with a C-terminal hemagglutinin (HA) tag provided by vector pCPP5372. HopAA1 variants shown to inhibit yeast growth are boxed. B, Production in the $\triangle \mathrm{IX} \triangle$ hopAA1-1 mutant of HopAA1-1 and the derivatives analyzed in panel A. Bacteria were grown in Hrp minimal medium. Protein samples were separated on a 7\% sodium dodecyl sulfate polyacrylamide gel, and immunoblot analysis was performed using antibodies to the HA tag at the $\mathrm{C}$ terminus of each test protein. 
behavior of the hopAA1-1::nptII/hopAA1-2::aadA1 double mutant suggests that the reduced lesion-number phenotype of the $\triangle \mathrm{IX} \triangle$ hopAA1-1 mutant involves some factor in cluster IX other than HopAA1-2.

The primary goal of constructing combinatorial deletions involving hopAA1-1 and other effector genes in DC3000 was to produce a mutant with a virulence defect that could be complemented by production of the native HopAA1-1, thus facilitating investigation of features of HopAA1-1 associated with virulence function. Importantly, the expression of HopAA1-1 restored parental levels of lesion formation to the $\Delta \mathrm{IX} \Delta$ hopAA1-1 mutant (Fig. 6A). With native HopAA1-1 available as a benchmark, we were able to test the various HopAA1-1 derivatives for their ability to promote virulence, including truncated derivatives that were previously constructed and tested for their toxicity when expressed in yeast (Munkvold et al. 2008). The two mutants that retained their ability to inhibit yeast growth (HopAA1-1 $1_{1-436}$ and HopAA1$\left.1_{\mathrm{R} 121 \mathrm{~A}}\right)$ also restored parental levels of lesion formation to the $\triangle \mathrm{IX} \Delta$ hopAA1-1 mutant, whereas the two mutants that lost the ability to inhibit yeast growth (HopAA1-1 $1_{1-386}$ and HopAA1$1_{\text {LRA-FEN }}$ ) similarly lost the ability to promote lesion formation. Thus, HopAA1-1 appears to have the same structural requirements for biological activity in yeast and plants.

\section{PSPTO4723 is responsible}

for the $\triangle \mathrm{IX}$ speck lesion and chlorosis phenotypes.

The DC3000 genomic region encompassed by the cluster IX deletion includes four active effector genes, one effector pseudogene with an associated insertion element, and two ORF of unknown function (PSPTO4719 and PSPTO4723) (Fig. 7A). To determine which gene or genes were responsible for the phenotypes associated with deleting cluster IX, we first tested each of the effectors, aside from HopAA1-2, for ability to restore higher levels of lesion formation to the $\triangle \mathrm{IX} \Delta$ hopAA1-1 mutant. We used the same expression vector employed above with HopAA1-1, but we observed no significant restoration of the lesion formation phenotype by any of these effectors (Fig. 8A). This lack of complementation did not appear to be due to a failure to produce these effectors, as immunoblot analysis confirmed that each was produced, although HopAO1 levels were lower in repeated analyses (Fig. 8B). To address the possibility that a combination of cluster IX effectors was needed to restore wild-type levels of speck lesions and diffuse chlorosis, we deleted the central 'inter-effector' region of pCPP5957 (Fig. 7). The resulting plasmid retained all four full-length effector genes but, nevertheless, failed to complement either the HopAA1-1-dependent lesion phenotype or the chlorosis phenotype associated with cluster IX (data not shown). These

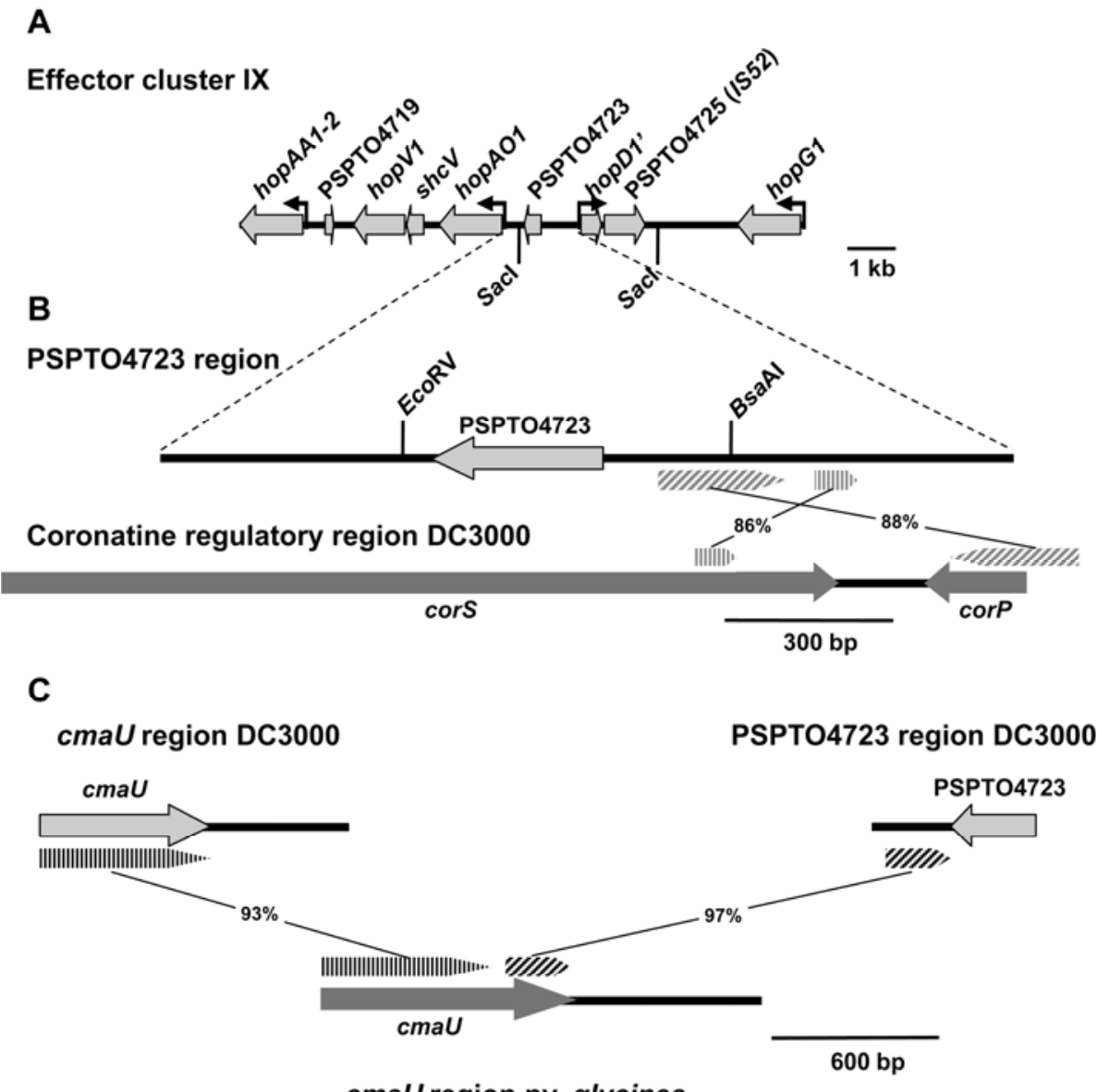

Fig. 7. Physical map of the effector-gene cluster IX region, including PSPTO4723 and fragmentary sequences with homology to genes directing coronatine production. A, The DC3000 chromosomal region that was deleted to remove effector-gene cluster IX encompasses hopAA1-2 through hopG1. Hrp promoters (black arrows) are located upstream of all four active hop genes, as well as the hopD1::IS52 pseudogene, which is disrupted by the PSPTO4725 IS52 transposase (the unexpressed region downstream is annotated as PSPTO4726 and is homologous to the $3^{\prime}$ sequence of an active hopD1 gene located in effectorgene cluster IV). The SacI sites used to delete the central 'inter-effector' region of pCPP5957 are shown. B, The region between hopAO1 and hopD1::IS52 is expanded to show PSPTO4723, restriction sites used to clone PSPTO4723 for complementation experiments, and regions with similarity to the coronatine regulatory region in DC3000 upstream of PSPTO4723. The percent identity between each region is shown. C, The region downstream of PSPTO4723 contains sequences with similarity to a portion of cmaU that is present in Pseudomonas syringae pv. glycinea but lacking in the DC3000 $\mathrm{cmaU}$. The percent identity between each region is shown. 
observations pointed to PSPTO4723 as being responsible for the cluster IX phenotypes.

PSPTO4723 displays no characteristics of an effector gene. It is not preceded by a Hrp promoter, and the predicted N-terminal sequence shows none of the amino-acid patterns associated with type III substrates (Lindeberg et al. 2006; Vinatzer et al. 2005). Analyses with WebACT (Abbott et al. 2005) and BLASTN revealed that PSPTO4723 is flanked by apparent pseudogene fragments of $\operatorname{cmaU}, \operatorname{cor} P$, and $\operatorname{corS}$ (Fig. 7BC). Active copies of these genes occur in DC3000 in the coronatine regulatory region and the $\mathrm{cma}$ gene cluster, which directs the biosynthesis of coronamic acid. Conjugation of coronafacic acid with coronamic acid produces coronatine, which is responsible for the chlorosis associated with DC3000 infections of tomato. Altered production of coronatine would be more consistent with the reduced chlorosis that is associated with the cluster IX deletion than loss of an effector.

To definitively test the role of PSPTO4723, we subcloned a 579-bp fragment containing PSPTO4723, and we precisely deleted the PSPTO4723 ORF from the DC3000 genome. We first attempted to PCR-clone the PSPTO4723 ORF under control of the nptII promoter in pBS46, but the resulting plasmid was unstable in DC3000. Subsequently, we used flanking BsaA1 and

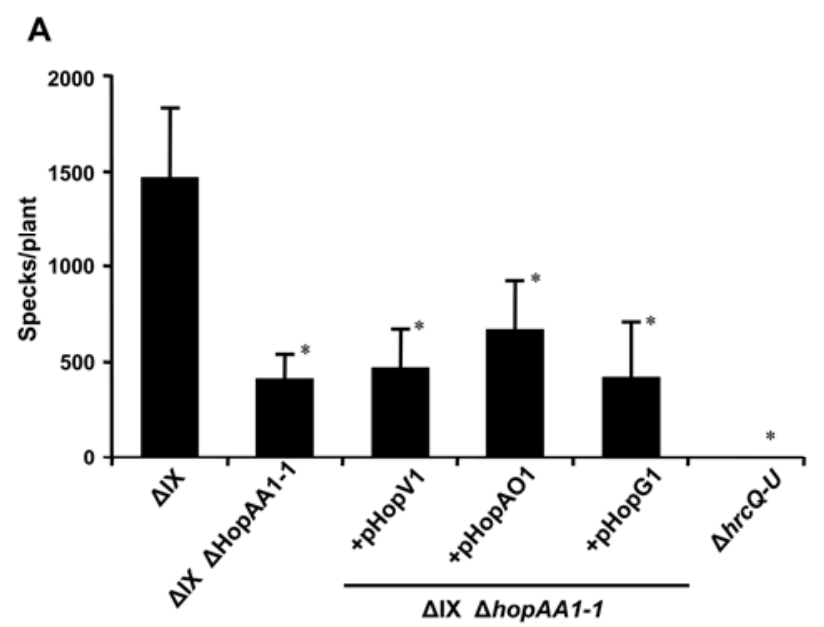

B

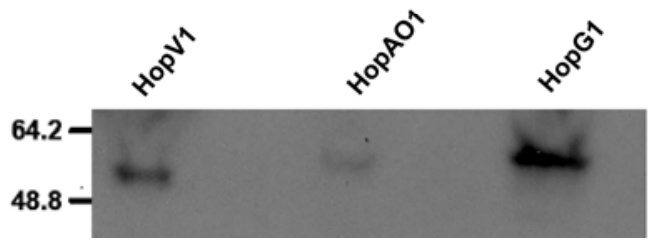

Fig. 8. The effectors HopV1, HopAO1, and HopG1 do not complement the HopAA1-1-associated lesion phenotype when expressed in trans. A, Number of lesions on tomato plants 5 days after being infected with the indicated strains in a dip inoculation at $1 \times 10^{5} \mathrm{CFU} / \mathrm{ml}$. The $\triangle \mathrm{IX} \triangle$ hopAA1-1 strains tested for complementation all have effectors expressed under control of a HrpL-dependent promoter and have a C-terminal hemagglutinin (HA) tag; this is abbreviated as phop with effectors further indicated. HopV1 is expressed with its chaperone, ShcV. The $\Delta h r c Q$ $U$ mutant is type III secretion system-minus CUCPB5113. Data values represent averages of three independent trials of two samples each, and error bars represent standard deviation. Asterisks mark strains that formed lesions at significantly different numbers $(P<0.05)$ than in an infection by the $\Delta \mathrm{IX}$ mutants as measured by a Student's $t$-test. B, Immunoblot confirming production of the indicated effector protein in complemented $\triangle \mathrm{IX} \Delta$ hopAA1-1 strains. HrpL-dependent expression of the proteins was induced by growing cultures overnight in Hrp minimal media. Pellets of these overnight cultures were then resolved on a 7\% sodium dodecyl sulfate polyacrylamide gel, after which an immunoblot was performed using a primary antibody against the C-terminal HA tags. Sizes determined by a protein ladder are marked in $\mathrm{kDa}$.
EcoRV sites to subclone from pCPP5956 the PSPTO4723 ORF along with 200 bp upstream and 50 bp downstream, which permitted expression of the gene without a vector promoter (Fig. 7B). A marked deletion of the PSPTO4723 ORF in both wild-type DC3000 and a $\triangle$ hopAAl-1 mutant was also constructed. The addition of the plasmid carrying the 579-bp fragment containing PSPTO4723 to a $\triangle \mathrm{IX} \Delta$ hopAA1-1 strain fully complemented lesion formation, and the $\triangle \mathrm{PSPTO} 4723$ mutants behaved in the same manner as $\Delta I X$ strains in exhibiting reduced chlorosis and a dependence upon HopAA1-1 for wild-type lesion formation (Fig. 9). Thus, PSPTO4723 appears to be responsible for the phenotypes associated with the deletion of the cluster IX region that we observed in this work.

\section{DISCUSSION}

By cloning and sequencing the hopAAl locus in the CEL of several $P$. syringae strains, we were able to discern a GAP-like domain in the N-proximal half of the predicted proteins. Introduction into HopAA1-1 of a polymorphism in this region found naturally in the DC3000 paralog, HopAA1-2, abolishes the ability of HopAA1-1 to be toxic in yeast and to promote

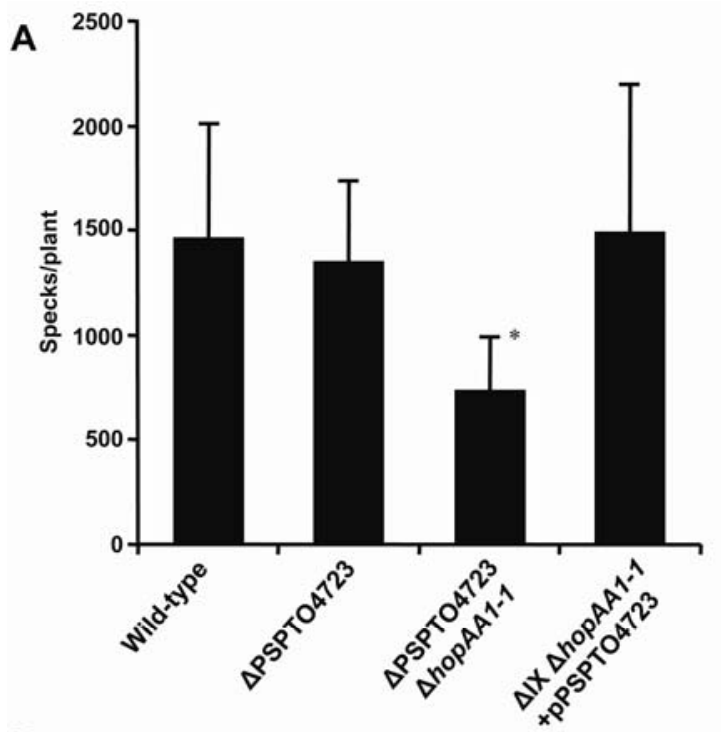

B

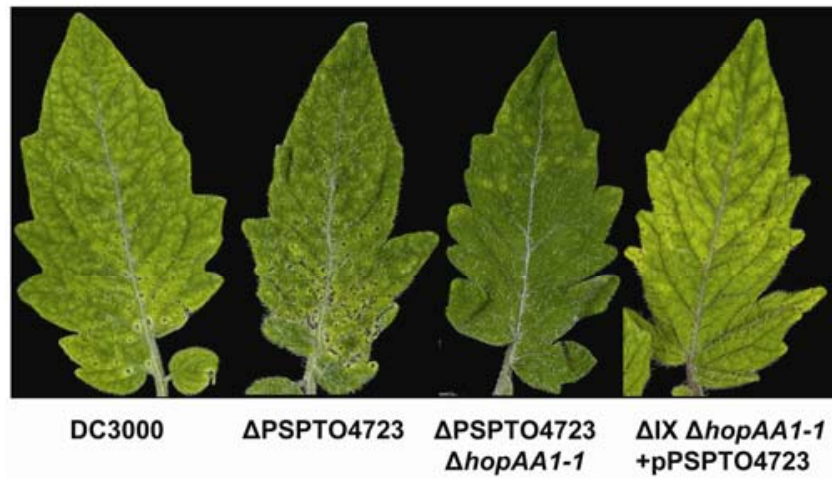

Fig. 9. PSPTO4723 is the major determinant of the cluster IX-associated speck and chlorosis symptoms in tomato. A, Speck lesion counts on tomato plants 5 days postinoculation from a dip inoculation with $1 \times 10^{5}$ CFU of the indicated strains per milliliter. Data represent averages from three independent trials of two samples each. Error bars represent standard deviations. Asterisks mark strains that produced lesions in tomato that were significantly different from those produced by wild-type DC3000, as measured by a Student's $t$-test $(P<0.01)$. B, Photographs of symptoms caused by selected strains at 5 days postinfection. Photographs show typical symptom formation for the selected strain. 
DC3000 virulence in host tomato. As is typical of $P$. syringae effectors, the contribution of HopAA1-1 to DC3000 virulence is best observed in a mutant background that reduces redundancy in virulence factors. Unexpectedly, the gene acting redundantly with hopAA1-1 is PSPTO4723, which encodes a conserved hypothetical protein and is necessary for the diffuse chlorosis that DC3000 infection produces in tomato leaves. Our discussion will address the function of HopAA1-1 in the context of current knowledge of $P$. syringae effector functions, the location of hopAAl-1 in the CEL, HopAA1-1 structural features, the functional interplay with PSPTO4723, and the possible relationship of coronatine production with HopAA1-1 function.

The parasitic success of $P$. syringae is thought to depend on the ability of type III effectors to suppress pathogen-associated molecular pattern (PAMP)-triggered immunity (PTI), while evading detection by (or suppressing) $R$ gene-mediated effector-triggered immunity (ETI), which is typically manifested in the hypersensitive response (Jones and Dangl 2006). The molecular functions of AvrPto and HopM1 provide examples suggesting that effectors interfere with at least two important processes in PTI, namely, PAMP perception and cell wall defense-associated vesicle trafficking, respectively (Nomura et al. 2006; Shan et al. 2008; Xiang et al. 2008). In addition, AvrPtoB provides an example of an effector that has multiple domains that may function to suppress PTI and to both elicit and suppress ETI (Abramovitch et al. 2003; Rosebrock et al. 2007; Xiao et al. 2007).

HopM1 is the best understood effector in the CEL and has been shown to suppress callose deposition, a cell wall-based PTI defense, and to target to the proteosome an ADP ribosylation factor guanine nucleotide exchange factor protein that is associated with vesicle trafficking (DebRoy et al. 2004; Nomura et al. 2006). Less is known about the molecular function of AvrE, but interestingly, observations based on mutant phenotypes and heterologous expression assays reveal that the three CEL effectors AvrE, HopM1, and HopAA1-1 make a larger contribution to lesion formation than they do to growth in planta and can cause cell death in host cells (Badel et al. 2003, 2006; Wei et al. 2007). Furthermore, whereas PAMP perception involves specific pattern-recognition receptor kinases and signaling components not likely to be found in yeast, defenseassociated vesicle trafficking and associated GTPases are likely universal among eukaryotes. Thus, the broad toxicity of transiently expressed HopAA1-1 to yeast and plant cells would be consistent with a primary role for this and other CEL effectors in disrupting fundamental cellular processes like vesicle trafficking.

It is also important to note that the $P$. syringae pv. syringae B728a hopAAl appears to have weak avirulence (ETI-eliciting) activity in Nicotiana benthamiana but not bean, as indicated by the lethality of transiently expressed hopAAl in $N$. benthamiana but not bean, and by the observation that a hopAA1 mutant is better able to grow in spray-inoculated $N$. benthamiana than wild-type B728a (Vinatzer et al. 2006). However, the toxicity of HopAA $1_{\text {Psy }}$ B728a to yeast that we observed here cannot easily be attributed to ETI, which raises the possibility that HopAA1 family members may promote cell death in plants by multiple means. It should also be noted that the DC3000 HopAA1-1 expressed in Arabidopsis protoplasts was able to suppress flagellin-induced accumulation of NONHOST1 (NHOl) transcripts, a marker for PTI-associated gene expression (Li et al. 2005). This observation suggests that HopAA1-1 can block PAMP perception, although it is possible that secondary effects of our proposed disruption of a basic cellular process like vesicle trafficking by HopAA1-1 contributed to this observation.
We presently have no evidence that HopAA1-1 has GAP activity or that such activity is required for biological function. The HopAA1- $1_{\mathrm{R} 121 \mathrm{~A}}$ mutation affecting the putative catalytic arginine had no effect on toxicity in yeast or virulence in tomato. Similarly, full-length HopAA1 family members from other phylogroups were still toxic to yeast despite the substitutions for the glycine in the GXLR motif that is found in type III effectors known to have GAP activity (Scheffzek and Ahmadian 2005). In contrast, the HopAA1- $1_{\text {LRA-FEN }}$ mutation abolished both the yeast and virulence phenotypes. This polymorphism, naturally occurring in HopAA1-2, involves the substitution of three amino acids with strongly different properties, which would be expected to significantly alter HopAA1-1 structure in this region, although it had no effect on the stability of the protein in yeast or $P$. syringae. We did not observe the FEN polymorphism in any of the CEL-associated HopAA1 family members we cloned from other strains. Interestingly, the region containing hopAAl-2 as well as the rest of the cluster IX effectors and the coronatine biosynthesis genes is missing from $P$. syringae pv. tomato T1 (Almeida et al. 2009), and hopAA1-2 is also missing from the sequenced strains $P$. syringae pv. syringae $\mathrm{B} 728 \mathrm{a}$ and $P$. syringae $\mathrm{pv}$. phaseolicola 1448A (Lindeberg et al. 2006).

Two aspects of the virulence phenotype resulting from the deletion of hopAAl-1 in a $\triangle \mathrm{IX}$ background warrant discussion. First, observing a $\triangle$ hopAA1-1 phenotype required deleting PSPTO4723. Importantly, PSPTO4723 does not appear to encode an effector and deleting this gene alone from DC3000 caused a striking reduction in the diffuse chlorosis associated with DC3000 infections in tomato. BLASTP analysis revealed PSPTO4723 to be in the DUF1330 family of proteins, which are widespread in members of phylum Proteobacteria but are of unknown function. PSPTO4723 is flanked by fragmentary sequences with similarity to genes associated with the regulation and production of coronatine. PSPTO4723 and the rest of the cluster IX region are part of variable region 107, an apparent genomic island that also contains the cfa and $\mathrm{cma}$ genes directing coronatine biosynthesis (Lindeberg et al. 2008). We are now pursuing the hypothesis that PSPTO4723 alters the production of coronatine during infection. The notion that altered coronatine production could enhance the $\triangle$ hopAAl-l lesion phenotype is consistent with several observations. DC3000 mutants altered in defined steps in coronatine biosynthesis are altered in lesion formation in tomato (Uppalapati et al. 2007), the regulation of coronatine and the T3SS in DC3000 are interconnected (Boch et al. 2002; Fouts et al. 2002; Peñaloza-Vázquez et al. 2000; Sreedharan et al. 2006), coronatine may promote programmed cell death in plants (Mach et al. 2001), and coronatine has been proposed to be a factor in triggering the necrogenic phase of the hemibiotrophic interaction of DC3000 with plants (Uppalapati et al. 2007). However, it is important to note that we have no evidence at this point of altered coronatine production or any causal relationship between the chlorosis and lesion phenotypes of mutants lacking PSPTO4723.

The second noteworthy aspect of the virulence phenotype resulting from the deletion of hopAAl-1 in a $\triangle \mathrm{IX}$ background is the significant reduction in the numbers of lesions produced in tomato leaves without a commensurate reduction in bacterial growth. As noted above, we have also observed that mutations in either $a v r E$ or hopM1 in DC3000 have a similar phenotype. In the future, we would like to learn if relatively subtle reductions in growth can have a disproportionate effect on lesion formation or whether specific effectors in the DC3000 repertoire directly control lesion formation. The observation that various $P$. syringae pathovars that become virulent on normally nonhost tomato (because of genetic manipulations blocking Pto/Prf-mediated 
ETI) produce symptoms characteristic of the diseases on their normal hosts indicates the importance of pathogen factors in directing symptom development (Lin and Martin 2007). Current models of effector function focus on the suppression of PTI and the evasion of ETI (Gohre and Robatzek 2008), which are considered to be early events in the infection. In contrast, lesion formation occurs late in the infection and is accompanied by the expression of defense genes associated with ETI and the cessation of bacterial growth (Tao et al. 2003). Although integrating these observations remains a challenge, the reduced speck phenotype we observed provides a useful bioassay for guiding exploration of the function of HopAA1-1 in pathogenesis. Additional challenges include determining the significance (if any, given the retention of biological activity by mutants altered in the putative catalytic arginine) of the GAP-like domain in HopAA1-1 and the basis for loss of activity in the associated LRA-FEN polymorphism. Another important challenge will be to understand how PSPTO4723 controls the production of diffuse chlorosis in infected leaves and how this apparent noneffector overlaps functionally with HopAA1-1 in promoting bacterial speck symptoms.

\section{MATERIALS AND METHODS}

\section{Plasmids, strains, and media.}

All strains and plasmids used in this study are presented in Table 2. Plasmids were maintained in Escherichia coli DH5 $\alpha$ except for pYES-DEST52, pCPP5447, pCPP5372, pCPP5296, and pBS46, all of which carry the $c c d B$ gene for counter-selection during Gateway cloning and, thus, were maintained in $E$. coli DB3.1. E. coli strains were grown at $37^{\circ} \mathrm{C}$ in Luria-Bertani medium, and Pseudomonas strains were grown at $30^{\circ} \mathrm{C}$ or room temperature in King's B (KB) medium or at room temperature in hrp minimal media (Huynh et al. 1989; King et al. 1954; Sambrook and Russel 2001). The following concentrations of antibiotics were used for all bacterial strains: ampicillin, 100; chloramphenicol, 20; gentamicin, 10; kanamycin, 50; rifampicin, 50; spectinomycin, 50; and cycloheximide, 4.

Drop out base (DOB) media (Qbiogene and Sunrise Science Products, Morgan Irvine and San Diego, CA, U.S.A., respectively) containing $2 \%$ glucose (Glc), $2 \%$ raffinose (Raf), or $1 \%$ raffinose and $2 \%$ galactose (Gal) as carbon sources was used for the growth of all yeast strains except for the RFY206 strain used in the creation of an effector-gene cluster IX clone; this strain was grown on YPAD media (Gietz et al. 1992), but after being transformed with the cluster IX clone, synthetic defined medium lacking uracil was used to maintain the plasmid. Plasmids were maintained in other strains by supplementing the media with complete supplement mixture lacking uracil (-Ura). Yeast strains were grown at $30^{\circ} \mathrm{C}$ in all cases.

\section{DNA manipulations.}

Standard molecular cloning procedures were used for creation, maintenance, and transformation of plasmid constructs

Table 2. Strains and plasmids

\begin{tabular}{|c|c|c|}
\hline Strain or plasmid & Genotype $^{\mathrm{a}}$ & Source or reference \\
\hline \multicolumn{3}{|l|}{ Escherichia coli } \\
\hline DH5 $\alpha$ & $\begin{array}{l}\mathrm{F}^{-} \text {Ф80lacZAM15 } \Delta \text { lacZYA-argF)U169 deoR recA1 endA1 hsdR17 phoA supE44 thi-1 } \\
\text { gyrA96 relA1 } \lambda^{-}\end{array}$ & Invitrogen \\
\hline DB3.1 & $\begin{array}{l}\mathrm{F}^{-} \text {gyrA462 endA1 } 1 \text { (srl-recA) mcrB mrr hsdS20 supE44 ara-14 galK2 lacY1 proA2 rpsL20 } \\
\text { xyl-5 } \lambda^{-} \text {-leu mtl-1 }\end{array}$ & Invitrogen \\
\hline XL1-Blue & 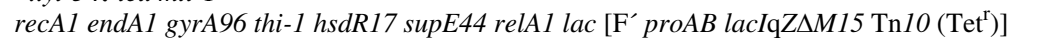 & Stratagene \\
\hline S17-1 & thi pro hsdr $h s d M^{+}$recA (chr::RP4-2-Tc::Mu- Km::Tn7) & \\
\hline \multicolumn{3}{|l|}{ Saccharomyces cerevisiae } \\
\hline BY4741a & MATa; his $3 \Delta 1 ;$ leu $2 \Delta 0 ;$ met $15 \Delta 0 ;$ ura $3 \Delta O$ & Brachmann et al. 1998 \\
\hline RFY206 & MATa his3 $\Delta 200$ leu2-3 lys $2 \Delta 201$ ura3-52 trp $1 \Delta::$ hisG & Finley and Brent 1994 \\
\hline \multicolumn{3}{|c|}{ Pseudomonas syringae pv. tomato } \\
\hline DC3000 & Wild type Rif ${ }^{r}$ & Buell et al. 2003 \\
\hline CUCPB5429 & effector cluster IX (hopAA1-2 /hopV1/hopAO1/hopGl) deletion mutant containing FRT scar & Wei et al. 2007 \\
\hline CUCPB5134 & hopAA1-1::nptII, hopAA1-2::aadA1 $\mathrm{Km}^{\mathrm{r}} \mathrm{Sp}^{\mathrm{r}}$ & Badel et al. 2002 \\
\hline CUCPB5113 & $\Delta$ hrcQbRSTU:: $\Omega$ aadAl $\mathrm{Sp}^{\mathrm{r}}$ & Badel et al. 2006 \\
\hline CUCPB5524 & hopAA1-1 deletion mutant containing a FRT-flanked cassette carrying aadAl $\mathrm{Sp}^{\mathrm{r}}$ & This study \\
\hline CUCPB5526 & $\begin{array}{l}\text { hopAA1-2 /hopV1/hopAO1/hopG1 deletion containing FRT scar, hopAA1-1 deletion } \\
\text { containing a FRT flanked cassette carrying } a a d A 1, \mathrm{Sp}^{\mathrm{r}}\end{array}$ & This study \\
\hline CUCPB5563 & PSPTO4723 deletion containing a FRT-flanked cassette carrying aadA1, $\mathrm{Sp}^{\mathrm{r}}$ & This study \\
\hline CUCPB5564 & $\begin{array}{l}\text { hopAA1-1 deletion marked with FRT scar; PSPTO4723 deletion containing a FRT-flanked } \\
\text { cassette carrying aadA1, } \mathrm{Sp}^{\mathrm{r}}\end{array}$ & This study \\
\hline \multicolumn{3}{|l|}{ Plasmids } \\
\hline $\mathrm{pENTR/SD/D-} \mathrm{TOPO}$ & Gateway entry vector, $\mathrm{Km}^{\mathrm{r}}$ & Invitrogen \\
\hline pCR2.1-TOPO & $\mathrm{TA}$ cloning vector; $\mathrm{Km}^{\mathrm{r}}$ and $\mathrm{Ap}^{\mathrm{r}}$ & Invitrogen \\
\hline pCPP5107 & pENTR/SD/D-TOPO::hopAA1-1 Pto DCзо0о & Munkvold et al. 2008 \\
\hline pCPP5108 & pENTR/SD/D-TOPO::hорAA1-2 & Munkvold et al. 2008 \\
\hline pCPP5409 & pENTR/SD/D-TOPO::hopAA1 & This study \\
\hline pCРP5348 & pENTR/SD/D-TOPO::hopAA1 $1_{P \text { ma ES4326 }}$ & This study \\
\hline pCPP5294 & pENTR/SD/D-TOPO::hopAA1 $1_{P S y B} B 28 a$ & This study \\
\hline pCPP5639 & pENTR/SD/D-TOPO::hopAA1 & This study \\
\hline pCРP5640 & pENTR/SD/D-TOPO::hopAA1 $1_{P l a}$ & This study \\
\hline pCPP5430 & pENTR/SD/D-TOPO::hopAA1 $1_{P t a A T C C 1528}$ & This study \\
\hline pCPP5351 & pENTR/SD/D-TOPO :: $P_{h r p} h o p A A 1-1_{P t o} D C 3000$ & This study \\
\hline pCPP5470 & pENTR/SD/D-TOPO::hopAA1-1 $1-436$ & Munkvold et al. 2008 \\
\hline pCРP5471 & pENTR/SD/D-TOPO::hopAA1-1 $1-386$ & Munkvold et al. 2008 \\
\hline pCPP5994 & pENTR/SD/D-TOPO::hopAA1-1 1 R101A & This study \\
\hline pCPP5995 & pENTR/SD/D-TOPO $:: h o p A A 1-1_{\text {LRA-FEN }}$ & This study \\
\hline pCPP5559 & pENTR/SD/D-TOPO $:: P_{h r p} h o p A A 1-1_{\mathrm{R} 121 \mathrm{~A}}$ & This study \\
\hline pCPP5560 & pENTR/SD/D-TOPO:: $P_{h r p} h o p A A 1-1_{\text {LRA-FEN }}$ & This study \\
\hline
\end{tabular}

${ }^{a} \mathrm{Ap}=$ ampicillin, $\mathrm{Km}=$ kanamycin, $\mathrm{Sp}=$ spectinomycin, and Rif = rifampicin. 
(Sambrook and Russel 2001). All primers used in this study were purchased from Integrated DNA Technologies (Skokie, IL, U.S.A.). DNA amplification was carried out with either Deep Vent DNA polymerase (New England Biolabs, Ipswich, MA, U.S.A.), cloned Pfu DNA polymerase (Stratagene, La Jolla, CA, U.S.A.), PrimeSTAR HS DNA polymerase, or ExTaq (Takara Bio Inc., Madison, WI, U.S.A.). DNA sequencing was performed on an Applied Biosystems Automated 3730 DNA Analyzer at the Cornell University Biotechnology Resource Center. Sequence analysis was carried out using Sequencher 4.2.2 software (Gene Codes Corporation, Ann Arbor, MI, U.S.A.).

\section{Cloning of hopAA1 family members.}

Genomic DNA was isolated from various $P$. syringae strains with the Wizard genomic DNA purification kit (Promega, Madison, WI, U.S.A.). Primers sets P1 and P2 and P3 and P4 were used to amplify the $3^{\prime}$ and $5^{\prime}$ regions of hopAAl homologs, respectively, from genomic DNA (Fig. 1; Table 3). Amplification products were cloned into pCR2.1-TOPO (Invitrogen, Carlsbad, CA, U.S.A.) via TA cloning. For each product, three individual clones were sequenced using primers complementary to the M13 priming sites present on the vector. For those assayed in subsequent experiments, new primer sets (P5 and P6) were designed to regions containing the predicted start and stop codons for each hopAA1 homolog as compared with hopAA1-1 $1_{\text {Pto DC3000 }}$ (Fig. 1; Table 3). Forward primers were designed to contain a 5' overhang of CACC- followed by 15 to 25 nucleotides beginning with the predicted start codon of the gene. Reverse primers were designed to the $3^{\prime} 17$ to 25 nucleotides of the gene but lacking the stop codon, to allow for expression of C-terminal fusion proteins. The amplification products were TOPO (Invitrogen) cloned into $\mathrm{pENTR/SD/D-TOPO.} \mathrm{Again,} \mathrm{three} \mathrm{individual} \mathrm{clones}$ for each hopAAl homolog were sequenced, using M13 primers. Sequencing of hopAAl $1_{\mathrm{Pta}}$ and hopAA $l_{\mathrm{Pag}}$ revealed the presence of a frameshift leading to a premature stop codon within the predicted coding sequence. For these homologs, a second reverse primer (P7) was designed to the new predicted stop codon (Fig. 1; Table 3). Amplification, cloning, and sequencing were carried out as described above.

In order to clone hopAAl homologs for which sequences previously had been deposited in GenBank (hopAA $l_{\text {Pma ES4326 }}$ and $h o p A A 1_{P_{s y} B 728 a}$ ), TOPO cloning primers were designed as described above to the regions containing the start and stop codons. Amplification, cloning, and sequencing were performed in the same manner as described above.

\section{Other plasmid and mutant constructions.}

DC3000 hopAAl-1 with its native promoter was cloned into $\mathrm{pENTR/SD/D-TOPO.} \mathrm{Amplification} \mathrm{of} 216$ basepairs upstream of the hopAA1-1 start codon to the $3^{\prime}$ end of the gene lacking the stop codon was carried out with primer pair P1829 and P1998. The amplification product was cloned via the directional

Table 2. (continued from previous page)

\begin{tabular}{|c|c|c|}
\hline Strain or plasmid & Genotype $^{\mathrm{a}}$ & Source or reference \\
\hline pCPP5372 & $\begin{array}{l}\text { pBBR1MCS containing avrPto promoter }\left(P_{\text {avrPto }}\right) \text {, Gateway reading frame B cassette, and C- } \\
\text { terminal HA tag; } \mathrm{Gm}^{\mathrm{r}} \mathrm{Cm}^{\mathrm{r}}\end{array}$ & Oh et al. 2007 \\
\hline pCPP5581 & pCPP5372::hopAA1-1 Pto DC3000 & This study \\
\hline pCPP5582 & pCPP5372::hорAA1-2 & This study \\
\hline pCРP5928 & pCPP5372: hopAA1-1 1-436 & This study \\
\hline pCРP5927 & pCРP5372::hopAA1-1 1-386 & This study \\
\hline pCPP5932 & pCPP5372:: $P_{h r p} h o p A A 1-1_{\mathrm{R} 121 \mathrm{~A}}$ & This study \\
\hline pCPP5933 & pCPP5372:: $P_{h r p}$ hopAA1-1 $1_{\text {LRA-FEN }}$ & This study \\
\hline pCPP5394 & $\begin{array}{l}\text { pENTR/D carrying 1-kb flanks for hopAA1-2-hopG1 deletion marked with FRT-flanked } \\
\text { aadA1, } \mathrm{Sp}^{\mathrm{r}} \mathrm{Km}^{\mathrm{r}}\end{array}$ & Wei et al. 2007 \\
\hline pBS46 & $\begin{array}{l}\text { pBBR1MCS5 containing Gateway reading frame B cassette for expression of HA-tagged } \\
\text { proteins from nptII promoter; Gm }\end{array}$ & Wei et al. 2007 \\
\hline pENTRgus & Gateway entry vector containing gus & Invitrogen \\
\hline pENTR11 & Gateway entry vector, MCS Km ${ }^{\mathrm{r}}$ & Invitrogen \\
\hline рСРP5929 & pBS46::gus; used as an empty vector control & This study \\
\hline pYES-DEST52 & Gatewaydestination vector $2 \mu, P_{G A L I}, \mathrm{ApR}, U R A 3$, adds a C-terminal V5-6His tag & Invitrogen \\
\hline pYES2/CT/LacZ & LacZ-V5-6his expressed from $\mathrm{P}_{G A L I} \cdot 2 \mu, \mathrm{Ap}^{\mathrm{r}}$ & Invitrogen \\
\hline pCPP5229 & pYES-DEST52 expressing HopAA1-1 Pto DC3000-V5-6his & Munkvold et al. 2008 \\
\hline pCPP5165 & pYES-DEST52 expressing HopAA1-2-V5-6his & Munkvold et al. 2008 \\
\hline pCPP5417 & pYES-DEST52 expressing HopAA $1_{\text {Pto T1-V5-6his }}$ & This study \\
\hline pCPP3286 & pYES-DEST52 expressing HopAA $1_{\text {Pma ES4326-V5-6his }}$ & This study \\
\hline pCPP5349 & pYES-DEST52 expressing HopAA1 $1_{\text {Psy B } 728 \mathrm{a}}$-V5-6his & This study \\
\hline рCРP3287 & pYES-DEST52 expressing HopAA1 $1_{\mathrm{Ppi}}$-V5-6his & This study \\
\hline pCPP5425 & pYES-DEST52 expressing HopAA1 $1_{\mathrm{Pla}}-\mathrm{V} 5-6 \mathrm{his}$ & This study \\
\hline рСРP5457 & pYES-DEST52 expressing HopAA $1_{\text {Pta ATCC11528-V5-6his }}$ & This study \\
\hline pCPP5492 & pYES-DEST52 expressing HopAA1-1 R121A $^{-V 5-6 h i s ~}$ & This study \\
\hline рСРР5493 & pYES-DEST52 expressing HopAA1- $1_{\text {LRA-FEN }}$-V5-6his & This study \\
\hline pCPP5950 & $\begin{array}{l}\text { LR recombinant between pYESDEST52 and } \mathrm{pCPP} 5394 \text {; recipient vector for yeast } \\
\text { recombination cloning of entire cluster IX, } \mathrm{Sp}^{\mathrm{r}} \mathrm{Ap}^{\mathrm{r}}\end{array}$ & This study \\
\hline рСРP5447 & pENTR/SD/D-TOPO::attP Gateway cassette $\mathrm{Km}^{\mathrm{r}}$ & This study \\
\hline pCРP5956 & pCPP5447:: hopAA1-2 $\rightarrow$ hopG1 $\mathrm{Km}^{\mathrm{r}}$ & This study \\
\hline pCРP5296 & pBBR1MCS containing Gateway reading frame B cassette and C-terminal $\mathrm{HA}$ tag; $\mathrm{Gm}^{\mathrm{r}} \mathrm{Cm}^{\mathrm{r}}$ & This study \\
\hline pCРP5957 & pCPP5296::hopAA1-2 $\rightarrow$ hopG1 $\mathrm{Gm}^{\mathrm{r}}$ & This study \\
\hline pK18mobsacB & Small mobilizable vector, $\mathrm{Km}^{\mathrm{r}}$, sucrose-sensitive $(\operatorname{sacB})$ & Schafer et al. 1994 \\
\hline pCPP5242 & pKD4 FRT cassette plasmid with nptII replaced by aadA1, $\mathrm{Sp}^{\mathrm{r}}$ & Wei et al. 2007 \\
\hline pCPP5924 & pK18mobsacB carrying the hopAAl-1 deletion flanks, $\mathrm{Km}^{\mathrm{r}}$ & This study \\
\hline pCРP5926 & $\begin{array}{l}\text { pCPP5924 with a FRT-flanked aadAl cassette in the deletion construct's central EcoRI site, } \\
\mathrm{Km}^{\mathrm{r}} \mathrm{Sp}^{\mathrm{r}}\end{array}$ & This study \\
\hline pCPP6000 & pENTR11::PSPTO4723 with promoter region & This study \\
\hline рСРP6001 & pCPP5296::PSPTO4723 with promoter region (=pPSPTO4723) & This study \\
\hline pCPP5998 & pK18mobsacB carrying the PSPTO4723 deletion construct. $\mathrm{Km}^{\mathrm{r}}$ & This study \\
\hline рСРP5999 & $\begin{array}{l}\text { pCPP5998 with a FRT-flanked cassette carrying aadAl cloned into the deletion construct's } \\
\text { central SpeI site. }\end{array}$ & This study \\
\hline
\end{tabular}


TOPO cloning reaction (Invitrogen). The resulting plasmid pCPP5351 was confirmed by DNA sequence analysis.

Site-directed mutagenesis of hopAAl-1 $1_{\text {Pto DC3000 }}$ and $P_{h r p}$ hopAA1-1 $1_{\text {Pto DC3000 }}$ was carried out using the QuikChange kit (Stratagene) on the entry vectors pCPP5107 and pCPP5351, respectively. For each mutation (R121A and LRA to FEN), complementary primers containing the mutated sequence were flanked by a minimum of 15 nucleotides of complementary sequence (P2646, P2647, P2648, P2649). Mutated plasmids were maintained in E. coli XL1-Blue, and mutations were confirmed by sequencing.

The Gateway destination vector pYES-DEST52 was recombined in an LR recombination reaction (Invitrogen) with the $\mathrm{pENTR/SD/D-TOPO} \mathrm{vectors} \mathrm{carrying} \mathrm{promoterless} \mathrm{hopAAl} \mathrm{ho-}$ mologs and hopAAl-1 $1_{\text {Pto DC3000 }}$ substitution mutants, generating vectors for yeast expression. Similarly, for expression in $P$. syringae for complementation experiments, the destination vector pCPP5372 was recombined in LR recombination reactions with pENTR/SD/D-TOPO vectors carrying hopAAl-1 and derivatives (pCPP5107, pCPP5471, pCPP5470, pCPP5559, and pCPP5560). The vector control pCPP5929 was obtained from an LR recombination between pBS46 and pENTR-gus from Invitrogen. The destination vector pBS46 is of similar origin to
pCPP5372, save for having an nptII promoter rather than a HrpL-activated promoter, and so, pBS46::gus was used as a vector control for complementation experiments.

For cluster IX complementation, the broad-host range Gateway destination vector pCPP5296 was created first by removing the Lac promoter from pBBR1MCS5 by SphI and KpnI restriction digestion followed by gel purification (Kovach et al. 1995). Next, the Gateway cassette and HA tag from pCPP5040 was amplified with primer pair P1817 and P1818 and was cloned into pBBRMCS5 via its SphI and KpnI sites (LópezSolanilla et al. 2004).

To delete the hopAA1-1 ORF from DC3000, flanking sequence was amplified with P2642 and P2643 and P2644 and P2645 and was ligated together using primer-introduced $E c o$ RI sites. The ligated fragment was then cloned into pK18mobsacB via HindIII and BamHI sites, yielding pCPP5924. An FRT-flanked cassette containing a gene conferring spectinomycin resistance was then amplified using P2640 and P2641, primers that added EcoRI sites to both ends of the cassette. This PCR product was then cloned into the central EcoRI site of pCPP5924 to create pCPP5926.

The PSPTO4723 deletion construct was made by amplifying a 1.5-kb region upstream of the ORF with P2661 and P2662

Table 3. Primers used

\begin{tabular}{|c|c|c|}
\hline Primer & Sequence $^{\mathrm{a}}$ & Target gene/restriction site \\
\hline P1828 & $5^{\prime}$ TCATGTCATCAAACTGCTT $3^{\prime}$ & $\mathrm{P} 1(h r p W)$ \\
\hline P1816 & 5' AGTGATATTTTTCGTCGCCAT 3' & $\mathrm{P} 2($ hopAA1-1) \\
\hline P1815 & 5' GCAGCCTGCCATCAACA 3' & P3 (hopAA1-1) \\
\hline P1827 & 5' TTGCGAAAGCTGATCAG 3' & P4 (PSPTO1371) \\
\hline P1834 & 5' CACCATGCACATCAACCGACCCG 3' & P5 (hopAA1 $\left.1_{P t o T I}\right)$ \\
\hline P1998 & 5' CGACCGCATAGGCCGAAAC 3' & P6 (hopAA1 $\left.1_{\text {Pto DC3000/TI }}\right)$ \\
\hline P1811 & 5' CACCATGTACATCAACCGCTCCATC $3^{\prime}$ & P5 (hopAA1 $1_{\text {Pma ES4326) }}$ \\
\hline P1812 & 5' TGGCCGCATTGCCTCGAAAG 3' & 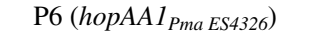 \\
\hline P1813 & 5' CACCATGCACATCAACCGAACCG 3' & P5 (hopAA1 $1_{P y B}$ B $\left.28 a\right)$ \\
\hline P1990 & 5' CACCATGCACATCAACCGAACCGG 3' & P5 $\left(h o p A A 1_{P p i}\right)$ \\
\hline $\mathrm{P} 1814$ & 5' TGAGCGCCCTGGCTGGAA 3' & P6 (hopAA1 $\left.1_{P s y / P p i}\right)$ \\
\hline P1838 & 5' CACCATGCACATCCACCGATC $3^{\prime}$ & P5 $\left(h o p A A 1_{P l a}\right)$ \\
\hline P1991 & 5' CGACCGCCCAGGCTGAA 3' & P6 $\left(h o p A A 1_{P l a}\right)$ \\
\hline P1995 & 5' CACCATGCACATCAACCGATCCG 3' & P5 (hopAA1 $\left.1_{\text {Pta/Pag }}\right)$ \\
\hline P1992 & 5' CGACCACCCAGGCTGAAACG 3' & P6 (hopAA1 $\left.1_{\text {Pta/Pag }}\right)$ \\
\hline P1988 & 5' TGGATGCCTGTCCGGCG 3' & P7 (hopAA1 $\left.1_{\text {Pta/Pag }}\right)$ \\
\hline P1829 & 5' CACCTGGGCGTACGCAGATTATTC 3' & $P_{h r p} h o p A A 1-1$ \\
\hline P2646 & 5' CTACATCAGGCGCGTTGGCGGCGACGCCCTTTGCC 3' & hopAA $1-1_{\mathrm{R} 121 \mathrm{~A}}$ \\
\hline P2647 & 5' GGCAAAGGGCGTCGCCGCCAACGCGCCTGATGTAG 3' & hopAA1-1 $1_{\mathrm{R} 121 \mathrm{~A} \text { complement }}$ \\
\hline P2648 & 5' CGACTACATCAGGCGCGTTTGAGAACACGCCCTTTGCC ATGGCC 3' & hopAA1-1 $1_{\mathrm{LRA}-\mathrm{FEN}}$ \\
\hline P2649 & 5' GGCCATGGCAAAGGGCGTGTTCTCAAACGCGCCTGATG TAGTCG 3' & hopAA1-1 $1_{\text {LRA-FEN complement }}$ \\
\hline P1817 & 5' TGAGCATGCACAAGTTTGTACAAAAAAGCTG 3' & $\operatorname{Sph} \mathrm{I}$ \\
\hline P1818 & 5' AGTGGTACC ACTCACTATAGGGAGTCC $3^{\prime}$ & KpnI \\
\hline P2642 & 5' TCTAAGCTTACGTAGGGGTAGGGCAGTGG 3' & HindIII \\
\hline P2643 & 5' TAGAATTCC GGTTGTTGGACGCGTCG $3^{\prime}$ & EcoRI \\
\hline P2644 & 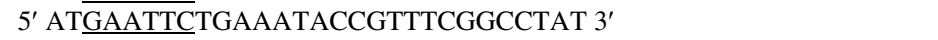 & EcoRI \\
\hline P2645 & 5' ACAGGATCCATCATGTCGTTGCTGCAGATG 3' & BamHI \\
\hline P2640 & 5' TAGAATTCGCTGGAGCTGCTTCGAA 3' & EcoRI \\
\hline P2641 & 5' ATGAATTCATGGGAATTAGCCATGGT 3' & EcoRI \\
\hline P1627 & 5' TATTAGATCTGGACATAAGCCTGTTCGGTT $3^{\prime}$ & $B g l I I$ \\
\hline P1628 & 5' TATTAGATCT TTATTTGCCGACTACCTTGG 3' & BglII \\
\hline P2512 & 5' CТАATCCACACCACCTGACG 3' & - \\
\hline $\mathrm{P} 2513$ & 5' CAAAGCGCTCACCTAGCTCT 3' & - \\
\hline P2514 & 5' AGTTGAAAGGTGATCTAGAGC 3' & - \\
\hline $\mathrm{P} 2515$ & 5' AGCTAGTTGGATTAATGCGG 3' & - \\
\hline P504 & 5' ATTGAATTCCACATCAACCGACGC 3' & EcoRI \\
\hline P505 & 5' ACA $\overline{\overline{G G A T C C}}$ TTACGACCGCATAG $3^{\prime}$ & EcoRI \\
\hline P2253 & 5' ATTACCTAGGGTGTAGGCTGGAGCTGCTTC 3' & AvrII \\
\hline P2254 & 5' ATTACCTAGGCATATGAATATCCTCCTTA $3^{\prime}$ & AvrII \\
\hline P2661 & $5^{\prime}$ TAATGAATTCTCAGTTCTGTAATCATGGCA 3' & EcoRI \\
\hline P2662 & 5' GCATACTAGT AACTAGAATTTACGCCATGA 3' & SpeI \\
\hline P2663 & 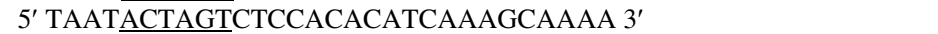 & SpeI \\
\hline P2664 & 5' TAATAAGCTTAATTGAAGTGTGCCATCCTG 3' & HindIII \\
\hline P2667 & 5' GCCACGCGGCGATAGGT 3' & - \\
\hline P2668 & 5' AGCGTTCGGTTCTCACGGTATCG 3' & - \\
\hline
\end{tabular}

${ }^{a}$ Underlined sequence designates restriction sites; bold sequence designates a mutation. 
and a 1-kb region downstream of PSPTO4723 with P2663 and P2664 and ligating the two together after a SpeI digest. The resulting 2.5-bp fragment was then cloned into pk18mobsacB with an EcoRI and HindIII digest. To mark the deletion the FRTSp $^{\mathrm{r}}$ cassette was amplified from pCPP5242 using P2253 and P2254 to add AvrII sites to both ends. This PCR product was then digested with AvrII and cloned into the central SpeI site of the deletion construct to create pCPP5999.

The PSPTO4723 expression vector was created by obtaining a 579-bp fragment from a $B s a \mathrm{~A} 1 / E c o \mathrm{RV}$ digest of pCPP5956 and cloning it into pENTR11 with an EcoRV/XmnI digest to create pCPP6000. Orientation was confirmed such that, when pCPP6000 was LR-cloned into pCPP5296 to create pCPP6001, the transcriptional terminator can provide robust termination for the transcript.

\section{Yeast growth inhibition assay.}

Saccharomyces cerevisiae BY4741a was transformed with pYES-DEST52 expression vectors carrying hopAAl homologs according to the lithium acetate transformation method (Gietz et al. 1992). Strains were inoculated into DOB Glc-Ura liquid culture and were grown overnight with shaking. The cultures were subinoculated into DOB Raf -Ura and, again, grown overnight with shaking. The following day, cultures were normalized to an optical density at $600 \mathrm{~nm}\left(\mathrm{OD}_{600}\right)$ of 0.45 in DOB Raf -Ura media using a Spectronic 20 (Bausch \& Lomb, Rochester, NY, U.S.A.). Cultures were serially diluted by $10-$ fold four times in the same media. Each dilution was dropped onto DOB Gal -Ura plates, was incubated for two days, and was photographed.

\section{Construction of deletion mutations.}

Suicide vectors containing deletion constructs were electrotransformed into E. coli $\mathrm{S} 17-1$ and delivered into $P$. syringae strains by conjugation. Transconjugants were plated on KB supplemented with kanamycin to select for integrants and both ampicillin and rifampicin to select against the donor strain. Resulting integrants were then plated on $10 \%$ sucrose plates supplemented with spectinomycin to counterselect the integrated vector while concurrently selecting for the deletion construct. Subsequent clones were also confirmed to be kanamycin-sensitive to ascertain that the counterselection was successful. Confirmation of the deletion of hopAAl-1 in CUCPB5526 came from Southern hybridization using the FRT-flanked cassette amplified by P1627 and P1628 from pCPP5242 as a probe, with an $\mathrm{MfeI}$ digest of genomic DNA, with a $4.2-\mathrm{kb}$ band indicative of correct marker exchange and deletion of hopAA1-1. The hopAA1-1::nptII/hopAA1-2::aadA1 double mutant was created in a previous study (Badel et al. 2002), as was the cluster IX deletion. (Wei et al. 2007). Confirmation of the PSPTO4723 deletion in CUCPB5563 and CUCPB5564 came from a PCR check using P2667 and P2668. In order to create the marked PSPTO4723 deletion in the already marked $\triangle h o p A A 1-1$ background, the FRT-flanked cassette had to first be removed from the hopAA1-1 mutant. To do this, the strain was transformed with pCPP5264, an easily cured plasmid expressing the FLP recombinase. After this transformation, the plasmid was cured and the removal of the FRT cassette was confirmed both by spectinomycin sensitivity and a PCR check using P504 and P505.

\section{Complementation of the effector-gene cluster IX deletion.}

pCPP5394, an entry vector containing a deletion construct for effector cluster IX of $P$. syringae DC3000 was LR recombined into pYESDEST52 to create pCPP5950. A 5.7-kb fragment of cluster IX amplified by P2512 and P2513 and a 7.3-kb fragment of cluster IX amplified by P2514 and P2515, using
HS Primestar DNA polymerase, were cotransformed into the yeast strain RFY206 along with BclI-linearized pCPP5950, using the procedure outlined in the Yeastmaker yeast transformation system 2 user manual from Clontech (Palo Alto, CA, U.S.A.). Fragments were designed such that they shared 35-bp regions of perfect homology with both one another and the vector backbone to allow for recombination-based assembly of the plasmid. Colonies were then plated on defined synthetic media lacking uracil to select for a successfully circularized plasmid. At this point, plasmids were obtained from a pool of yeast and were transformed into DH5 $\alpha$, after which they were screened for a correctly assembled recombinant plasmid. The resulting plasmid was BP cloned into pCPP5447, the product of recombination between $\mathrm{pENTR/SD/D-TOPO}$ and a Gateway Destination vector containing reading frame $\mathrm{A}$, to create the entry vector, pCPP5956. pCPP5956 was then LR cloned into pCPP5296 to create the cluster IX expression vector pCPP5957, which was then electrotransformed into CUCPB5526 and was maintained through gentamicin selection to create the complemented strain.

\section{Plant materials and bacterial virulence assays.}

Tomato (Solanum lycopersicum cv. Moneymaker) plants, 3.5 to 4 weeks postgermination, were used in virulence growth and symptom assays. All symptom assays were performed by dip inoculation, whereas growth assays were performed both by blunt-syringe infiltration and dip inoculation. Plants were grown under greenhouse conditions. For dipping assays, plants were transferred to a growth chamber with $50 \%$ relative humidity and a 16-h day and were covered with autoclave bags to increase humidity and open stomata $24 \mathrm{~h}$ before infiltration. No such steps were taken for syringe-infiltration assays. Syringe infiltrations were performed as previously described (Alfano et al. 1996), infiltrating the youngest fully expanded leaves that were large enough to take leaf tissue from. For syringe-inoculation assays, 2-day-old lawns were harvested off solid KB media and were resuspended in $100 \mathrm{mM}$ sucrose, $10 \mathrm{mM}$ $\mathrm{MgCl}_{2}$ to an $\mathrm{OD}_{600}$ of 0.3 . The resulting suspension was diluted in $10 \mathrm{mM}$ sucrose for a final bacterial count of $1 \times 10^{4} \mathrm{CFU}$ per milliliter. This suspension was then inoculated into plant leaves using a blunt syringe. For competitive growth indices, equal amounts of the $1 \times 10^{4}$ suspensions of each strain were mixed for the final inoculum. Plants were then kept at $80 \%$ relative humidity with a 12 -h day at $25^{\circ} \mathrm{C}$ for 3 days postinfection, at which point, tissue was harvested for growth counts.

Dip assays were performed as previously described (Wei et al. 2007), with bacteria also being resuspended from 2-day-old plates in $100 \mathrm{mM}$ sucrose, $10 \mathrm{mM} \mathrm{MgCl}_{2}$ to an $\mathrm{OD}_{600}$ of 0.3 . This suspension was diluted in 1 liter of water with $0.02 \%$ Silwet $\mathrm{L} 77$ to $1 \times 10^{5} \mathrm{CFU} / \mathrm{ml}$. Plants were dipped into the bacterial suspension and were swirled for $30 \mathrm{~s}$ and were allowed to air dry. Plants were then kept in a growth chamber with a $16-\mathrm{h}$ day at $24^{\circ} \mathrm{C}$ during the day and $20^{\circ} \mathrm{C}$ at night with $50 \%$ relative humidity for either 3 days for growth assays or 5 days for growth and symptom assays.

For growth assays, counts were obtained from initial inoculum by diluting and plating on KB media and also, in order to determine the input ratio in competitive indices, on KB supplemented with spectinomycin. At either day 3 or 5 after inoculation, leaf tissue was harvested and ground in $100 \mathrm{mM}$ sucrose, $10 \mathrm{mM} \mathrm{MgCl} 2$ and was plated as a series of dilutions on $\mathrm{KB}$ agar supplemented with cycloheximide. For competitive indices, dilutions were also plated on KB agar supplemented with spectinomycin and cycloheximide to determine final growth ratios. For syringe infiltrations, $1.5 \mathrm{~cm}^{2}$ of tissue was harvested, and for dip assays, $2 \mathrm{~cm}^{2}$ of tissue was harvested. Competitive indices and relative increase ratios were calculated as previ- 
ously described (Macho et al. 2007). Symptom assays were completed 5 days after inoculation. Specks were visually scored as chlorotic lesions with necrotic centers. The entire plant was scored, and the data represent an average number of specks per plant. All datapoints represent three independent trials of two plants apiece.

\section{Immunoblot analyses.}

In order to confirm production of HopAA1-1 variants in yeast and $P$. syringae, immunoblot analyses were performed. Yeast samples were prepared as previously described (Munkvold et al. 2008). P. syringae strains were grown in Hrp-minimal media overnight, to induce HrpL-dependent expression of vectors. Bacteria in these overnight broths were harvested by centrifugation, and proteins in the pellet fraction resolved with a $7 \%$ sodium dodecyl sulfate-polyacrylamide gel. Yeast and bacterial proteins were blotted onto an Immobilon P transfer membrane from Millipore (Bedford, MA, U.S.A.) using a Hoefer SemiPhor semidry transfer unit. The membrane was blotted using a high-affinity rat monoclonal anti-HA antibody from Roche Diagnostics (Mannheim, Germany) and a secondary anti-rat antibody conjugated to alkaline phosphatase from Sigma-Aldrich (Tokyo). The membrane was then incubated with chemiluminescent substrate before being exposed on X-ray film.

\section{ACKNOWLEDGMENTS}

We thank S. Cunnac for suggesting in vivo assembly of effector cluster IX in yeast, D. J. Schneider for useful discussions regarding PSPTO4723 bioinformatics, and K. Loeffler for photography. This work was supported by National Science Foundation Plant Genome Research Program grant DBI-0605059.

\section{LITERATURE CITED}

Abbott, J. C., Aanensen, D. M., Rutherford, K., Butcher, S., and Spratt, B. G. 2005. WebACT - an online companion for the Artemis Comparison Tool. Bioinformatics 21:3665-3666.

Abramovitch, R. B., Kim, Y. J., Chen, S., Dickman, M. B., and Martin, G. B. 2003. Pseudomonas type III effector AvrPtoB induces plant disease susceptibility by inhibition of host programmed cell death. EMBO (Eur. Mol. Biol. Organ.) J 22:60-69.

Alfano, J. R., Bauer, D. W., Milos, T. M., and Collmer, A. 1996. Analysis of the role of the Pseudomonas syringae pv. syringae HrpZ harpin in elicitation of the hypersensitive response in tobacco using functionally nonpolar deletion mutations, truncated HrpZ fragments, and hrmA mutations. Mol. Microbiol. 19:715-728.

Alfano, J. R., Charkowski, A. O., Deng, W.-L., Badel, J. L., PetnickiOcwieja, T., van Dijk, K., and Collmer, A. 2000. The Pseudomonas syringae Hrp pathogenicity island has a tripartite mosaic structure composed of a cluster of type III secretion genes bounded by exchangeable effector and conserved effector loci that contribute to parasitic fitness and pathogenicity in plants. Proc. Natl. Acad. Sci. U.S.A. 97:4856-4861.

Almeida, N. F., Yan, S., Lindeberg, M., Studholme, D. J., Schneider, D. J., Condon, B., Liu, H., Viana, C. J., Warren, A., Evans, C., Kemen, E., MacLean, D., Angot, A., Martin, G. B., Jones, J. D., Collmer, A., Setubal, J. C., and Vinatzer, B. A. 2009. A draft genome sequence of Pseudomonas syringae pv. tomato T1 reveals a type III effector repertoire significantly divergent from that of Pseudomonas syringae pv. tomato DC3000 Mol. Plant-Microbe Interact. 22:52-62.

Badel, J. L., Charkowski, A. O., Deng, W.-L., and Collmer, A. 2002. A gene in the Pseudomonas syringae pv. tomato Hrp pathogenicity island conserved effector locus, hopPtoA1, contributes to efficient formation of bacterial colonies in planta and is duplicated elsewhere in the genome. Mol. Plant-Microbe Interact. 15:1014-1024.

Badel, J. L., Nomura, K., Bandyopadhyay, S., Shimizu, R., Collmer, A., and He, S. Y. 2003. Pseudomonas syringae pv. tomato DC3000 HopPtoM (CEL ORF3) is important for lesion formation but not growth in tomato and is secreted and translocated by the Hrp type III secretion system in a chaperone-dependent manner. Mol. Microbiol. 49:1239-1251.

Badel, J. L., Shimizu, R., Oh, H.-S., and Collmer, A. 2006. A Pseudomonas syringae pv. tomato avrE1/hopM1 mutant is severely reduced in growth and lesion formation in tomato. Mol. Plant-Microbe Interact. 19:99-111.
Block, A., Li, G., Fu, Z. Q., and Alfano, J. R. 2008. Phytopathogen type III effector weaponry and their plant targets. Curr. Opin. Plant Biol. 11:396-403.

Boch, J., Joardar, V., Gao, L., Robertson, T. L., Lim, M., and Kunkel, B. N. 2002. Identification of Pseudomonas syringae genes induced during infection of Arabidopsis thaliana. Mol. Microbiol. 44:73-88.

Bogdanove, A. J., Bauer, D. W., and Beer, S. V. 1998a. Erwinia amylovora secretes DspE, a pathogenicity factor and functional AvrE homolog, through the Hrp (type III secretion) pathway. J. Bacteriol. 180:2244-2247.

Bogdanove, A. J., Kim, J. F., Wei, Z., Kolchinsky, P., Charkowski, A. O., Conlin, A. K., Collmer, A., and Beer, S. V. 1998b. Homology and functional similarity of an $h r p$-linked pathogenicity locus, $d s p E F$, of $E r$ winia amylovora and the avirulence locus avrE of Pseudomonas syringae pathovar tomato. Proc. Natl. Acad. Sci. U.S.A. 95:1325-1330.

Brachmann, C. B., Davies, A., Cost, G. J., Caputo, E., Li, J., Hieter, P., and Boeke, J. D. 1998. Designer deletion strains derived from Saccharomyces cerevisiae S288C: A useful set of strains and plasmids for PCR-mediated gene disruption and other applications. Yeast 14:115-132.

Buell, C. R., Joardar, V., Lindeberg, M., Selengut, J., Paulsen, I. T., Gwinn, M. L., Dodson, R. J., Deboy, R. T., Durkin, A. S., Kolonay, J. F., Madupu, R., Daugherty, S., Brinkac, L., Beanan, M. J., Haft, D. H., Nelson, W. C., Davidsen, T., Liu, J., Yuan, Q., Khouri, H., Fedorova, N., Tran, B., Russell, D., Berry, K., Utterback, T., Vanaken, S. E. Feldblyum, T. V., D’Ascenzo, M., Deng, W.-L., Ramos, A. R., Alfano, J. R., Cartinhour, S., Chatterjee, A. K., Delaney, T. P., Lazarowitz, S. G., Martin, G. B., Schneider, D. J., Tang, X., Bender, C. L., White, O., Fraser, C. M., and Collmer, A. 2003. The complete sequence of the Arabidopsis and tomato pathogen Pseudomonas syringae pv. tomato DC3000. Proc. Natl. Acad. Sci. U.S.A. 100:10181-10186.

Chang, J. H., Urbach, J. M., Law, T. F., Arnold, L. W., Hu, A., Gombar, S., Grant, S. R., Ausubel, F. M., and Dangl, J. L. 2005. A high-throughput, near-saturating screen for type III effector genes from Pseudomonas syringae. Proc. Natl. Acad. Sci. U.S.A. 102:2549-2554.

Cornelis, G. R. 2006. The type III secretion injectisome. Nat. Rev. Microbiol. 4:811-825.

Cunnac, S., Lindeberg, M., and Collmer, A. 2009. Pseudomonas syringae type III secretion system effectors: Repertoires in search of functions. Curr. Opin. Microbiol. 12:53-60.

DebRoy, S., Thilmony, R., Kwack, Y. B., Nomura, K., and He, S. Y. 2004. A family of conserved bacterial effectors inhibits salicylic acid-mediated basal immunity and promotes disease necrosis in plants. Proc. Natl. Acad. Sci. U.S.A. 101:9927-9932.

Feil, H., Feil, W. S., Chain, P., Larimer, F., Dibartolo, G., Copeland, A., Lykidis, A., Trong, S., Nolan, M., Goltsman, E., Thiel, J., Malfatti, S., Loper, J. E., Lapidus, A., Detter, J. C., Land, M., Richardson, P. M. Kyrpides, N. C., Ivanova, N., and Lindow, S. E. 2005. Comparison of the complete genome sequences of Pseudomonas syringae pv. syringae B728a and pv. tomato DC3000. Proc. Natl. Acad. Sci. U.S.A. 102:11064-11069.

Finley, R. L., Jr., and Brent, R. 1994. Interaction mating reveals binary and ternary connections between Drosophila cell cycle regulators. Proc. Natl. Acad. Sci. U.S.A. 91:12980-12984.

Fouts, D. E., Abramovitch, R. B., Alfano, J. R., Baldo, A. M., Buell, C. R., Cartinhour, S., Chatterjee, A. K., D’Ascenzo, M., Gwinn, M. L., Lazarowitz, S. G., Lin, N.-C., Martin, G. B., Rehm, A. H., Schneider, D. J., van Dijk, K., Tang, X., and Collmer, A. 2002. Genomewide identification of Pseudomonas syringae pv. tomato DC3000 promoters controlled by the HrpL alternative sigma factor. Proc. Natl. Acad. Sci. U.S.A. 99:2275-2280.

Fu, Y., and Galán, J. E. 1999. A Salmonella protein antagonizes Rac-1 and Cdc42 to mediate host-cell recovery after bacterial invasion. Nature 401:293-297.

Gaudriault, S., Malandrin, L., Paulin, J.-P., and Barny, M.-A. 1997. DspA, an essential pathogenicity factor of Erwinia amylovora showing homology with AvrE of Pseudomonas syringae, is secreted via the Hrp secretion pathway in a DspB-dependent way. Mol. Microbiol. 26:1057-1069.

Gietz, D., St Jean, A., Woods, R. A., and Schiestl, R. H. 1992. Improved method for high efficiency transformation of intact yeast cells. Nucleic Acids Res. 20:1425.

Goehring, U. M., Schmidt, G., Pederson, K. J., Aktories, K., and Barbieri, J. T. 1999. The N-terminal domain of Pseudomonas aeruginosa exoenzyme $\mathrm{S}$ is a GTPase-activating protein for Rho GTPases. J. Biol. Chem. 274:36369-36372.

Gohre, V., and Robatzek, S. 2008. Breaking the barriers: Microbial effector molecules subvert plant immunity. Annu. Rev. Phytopathol. 46:189-215.

Ham, J. H., Majerczak, D. R., Arroyo-Rodriguez, A. S., Mackey, D. M., and Coplin, D. L. 2006. WtsE, an AvrE-family effector protein from Pantoea stewartii subsp. stewartii, causes disease-associated cell death in corn and requires a chaperone protein for stability. Mol Plant Microbe Interact 19:1092-1102. 
Huynh, T. V., Dahlbeck, D., and Staskawicz, B. J. 1989. Bacterial blight of soybean: Regulation of a pathogen gene determining host cultivar specificity. Science 245:1374-1377.

Joardar, V., Lindeberg, M., Jackson, R. W., Selengut, J., Dodson, R., Brinkac, L. M., Daugherty, S. C., DeBoy, R., Durkin, A. S., Giglio, M. G., Madupu, R., Nelson, W. C., Rosovitz, M. J., Sullivan, S., Haft, D. H., Creasy, T., Davidsen, T., Zafar, N., Zhou, L., Halpin, R., Holley, T., Khouri, H., Feldblyum, T., White, O., Fraser, C. M., Chatterjee, A. K., Cartinhour, S., Schneider, D. J., Mansfield, J., Collmer, A., and Buell, C. R. 2005. Whole genome sequence analysis of Pseudomonas syringae pv. phaseolicola 1448A reveals sequence divergence among pathovars in genes involved in virulence and mobile genetic elements. J. Bacteriol 187:6488-6498.

Jones, J. D., and Dangl, J. L. 2006. The plant immune system. Nature 444:323-329.

King, E. O., Ward, M. K., and Raney, D. E. 1954. Two simple media for the demonstration of pyocyanin and fluorescin. J. Lab. Clin. Med. 44:301-307.

Kovach, M. E., Elzer, P. H., Hill, D. S., Robertson, G. T., Farris, M. A., Roop, R. M., 2nd, and Peterson, K. M. 1995. Four new derivatives of the broad-host-range cloning vector pBBR1MCS, carrying different antibiotic-resistance cassettes. Gene 166:175-176.

Kvitko, B. H., Park, D. H., Velásquez, A. C., Wei, C.-F., Russell, A. B., Martin, G. B., Schneider, D. J., and Collmer, A. 2009. Deletions in the repertoire of Pseudomonas syringae pv. tomato DC3000 type III secretion effector genes reveal functional overlap among effectors. PLoS Pathog. 5:e1000388.

Li, X., Lin, H., Zhang, W., Zou, Y., Zhang, J., Tang, X., and Zhou, J. M. 2005. Flagellin induces innate immunity in nonhost interactions that is suppressed by Pseudomonas syringae effectors. Proc. Natl. Acad. Sci. U.S.A. 102:12990-12995

Lin, N.-C., and Martin, G. B. 2007. Pto/Prf-mediated recognition of AvrPto and AvrPtoB restricts the ability of diverse Pseudomonas syringae pathovars to infect tomato. Mol. Plant-Microbe Interact. 20:806-815.

Lindeberg, M., Stavrinides, J., Chang, J. H., Alfano, J. R., Collmer, A. Dangl, J. L., Greenberg, J. T., Mansfield, J. W., and Guttman, D. S. 2005. Proposed guidelines for a unified nomenclature and phylogenetic analysis of type III Hop effector proteins in the plant pathogen Pseudomonas syringae. Mol. Plant-Microbe Interact. 18:275-282.

Lindeberg, M., Cartinhour, S., Myers, C. R., Schechter, L. M., Schneider, D. J., and Collmer, A. 2006. Closing the circle on the discovery of genes encoding Hrp regulon members and type III secretion system effectors in the genomes of three model Pseudomonas syringae strains. Mol. Plant-Microbe Interact. 19:1151-1158.

Lindeberg, M., Myers, C. R., Collmer, A., and Schneider, D. J. 2008 Roadmap to new virulence determinants in Pseudomonas syringae: Insights from comparative genomics and genome organization. Mol. PlantMicrobe Interact. 21:685-700.

López-Solanilla, E., Bronstein, P. A., Schneider, A. R., and Collmer, A 2004. HopPtoN is a Pseudomonas syringae Hrp (type III secretion system) cysteine protease effector that suppresses pathogen-induced necrosis associated with both compatible and incompatible plant interactions. Mol. Microbiol. 54:353-365.

Mach, J. M., Castillo, A. R., Hoogstraten, R., and Greenberg, J. T. 2001 The Arabidopsis-accelerated cell death gene ACD2 encodes red chlorophyll catabolite reductase and suppresses the spread of disease symptoms. Proc. Natl. Acad. Sci. U.S.A. 98:771-776.

Macho, A. P., Zumaquero, A., Ortiz-Martin, I., and Beuzon, C. R. 2007. Competitive index in mixed infections: A sensitive and accurate assay for the genetic analysis of Pseudomonas syringae-plant interactions. Mol. Plant Pathol. 8:437-450.

Munkvold, K. R., Martin, M. E., Bronstein, P. A., and Collmer, A. 2008. A survey of the Pseudomonas syringae pv. tomato DC3000 type III secretion system effector repertoire reveals several effectors that are deleterious when expressed in Saccharomyces cerevisiae. Mol. Plant-Microbe Interact. 21:490-502.

Nomura, K., Debroy, S., Lee, Y. H., Pumplin, N., Jones, J., and He, S. Y. 2006. A bacterial virulence protein suppresses host innate immunity to cause plant disease. Science 313:220-223.

Oh, H.-S., Kvitko, B. H., Morello, J. E., and Collmer, A. 2007. Pseudomonas syringae lytic transglycosylases co-regulated with the type III secretion system contribute to the translocation of effector proteins into plant cells. J. Bacteriol. 189:8277-8289.

Peñaloza-Vázquez, A., Preston, G. M., Collmer, A., and Bender, C. L. 2000. Regulatory interactions between the Hrp type III protein secretion system and coronatine biosynthesis in Pseudomonas syringae pv. tomato DC3000. Microbiology 146:2447-2456.

Rohmer, L., Guttman, D. S., and Dangl, J. L. 2004. Diverse evolutionary mechanisms shape the type III effector virulence factor repertoire in the plant pathogen Pseudomonas syringae. Genetics 167:1341-1360.

Rosebrock, T. R., Zeng, L., Brady, J. J., Abramovitch, R. B., Xiao, F., and Martin, G. B. 2007. A bacterial E3 ubiquitin ligase targets a host protein kinase to disrupt plant immunity. Nature 448:370-374.

Sambrook, J., and Russel, D. W. 2001. Molecular Cloning: A Laboratory Manual. Cold Spring Harbor Laboratory Press, Cold Spring Harbor, NY, U.S.A.

Sarkar, S. F., and Guttman, D. S. 2004. Evolution of the core genome of Pseudomonas syringae, a highly clonal, endemic plant pathogen. Appl. Environ. Microbiol. 70:1999-2012.

Sawada, H., Suzuki, F., Matsuda, I., and Saitou, N. 1999. Phylogenetic analysis of Pseudomonas syringae pathovars suggests the horizontal gene transfer of $\arg K$ and the evolutionary stability of $h r p$ gene cluster. J. Mol. Evol. 49:627-644.

Schafer, A., Tauch, A., Jager, W., Kalinowski, J., Thierbach, G., and Puhler, A. 1994. Small mobilizeable multi-purpose cloning vectors derived from the Escherichia coli plasmids pK18 and pK19: Selection of defined deletions in the chromosome of Corynebacterium glutamicum Gene 145:69-73.

Schechter, L. M., Vencato, M., Jordan, K. L., Schneider, S. E., Schneider, D. J., and Collmer, A. 2006. Multiple approaches to a complete inventory of Pseudomonas syringae pv. tomato DC3000 type III secretion system effector proteins. Mol. Plant-Microbe Interact. 19:1180-1192.

Scheffzek, K., and Ahmadian, M. R. 2005. GTPase activating proteins: Structural and functional insights 18 years after discovery. Cell Mol. Life Sci. 62:3014-3038.

Scheffzek, K., Ahmadian, M. R., Kabsch, W., Wiesmuller, L., Lautwein, A., Schmitz, F., and Wittinghofer, A. 1997. The Ras-RasGAP complex: Structural basis for GTPase activation and its loss in oncogenic Ras mutants. Science 277:333-338.

Shan, L., He, P., Li, J., Heese, A., Peck, S. C., Nurnberger, T., Martin, G. B., and Sheen, J. 2008. Bacterial effectors target the common signaling partner BAK1 to disrupt multiple MAMP receptor-signaling complexes and impede plant immunity. Cell Host Microbe 4:17-27.

Sreedharan, A., Penaloza-Vazquez, A., Kunkel, B. N., and Bender, C. L. 2006. CorR regulates multiple components of virulence in Pseudomonas syringae pv. tomato DC3000. Mol. Plant-Microbe Interact. 19:768 779.

Tao, Y., Xie, Z., Chen, W., Glazebrook, J., Chang, H. S., Han, B., Zhu, T., Zou, G., and Katagiri, F. 2003. Quantitative nature of Arabidopsis responses during compatible and incompatible interactions with the bacterial pathogen Pseudomonas syringae. Plant Cell 15:317-330.

Thompson, J. D., Gibson, T. J., Plewniak, F., Jeanmougin, F., and Higgins, D. G. 1997. The CLUSTAL_X windows interface: Flexible strategies for multiple sequence alignment aided by quality analysis tools. Nucleic Acids Res. 25:4876-4882.

Uppalapati, S. R., Ishiga, Y., Wangdi, T., Kunkel, B. N., Anand, A., Mysore, K. S., and Bender, C. L. 2007. The phytotoxin coronatine contributes to pathogen fitness and is required for suppression of salicylic acid accumulation in tomato inoculated with Pseudomonas syringae pv. tomato DC3000. Mol. Plant-Microbe Interact. 20:955-965.

Vinatzer, B. A., Jelenska, J., and Greenberg, J. T. 2005. Bioinformatics correctly identifies many type III secretion substrates in the plant pathogen Pseudomonas syringae and the biocontrol isolate $P$. fluorescens SBW25. Mol. Plant-Microbe Interact. 18:877-888.

Vinatzer, B. A., Teitzel, G. M., Lee, M. W., Jelenska, J., Hotton, S., Fairfax, K., Jenrette, J., and Greenberg, J. T. 2006. The type III effector repertoire of Pseudomonas syringae pv. syringae B728a and its role in survival and disease on host and non-host plants. Mol. Microbiol. 62:26-44.

Von Pawel-Rammingen, U., Telepnev, M. V., Schmidt, G., Aktories, K., Wolf-Watz, H., and Rosqvist, R. 2000. GAP activity of the Yersinia YopE cytotoxin specifically targets the Rho pathway: A mechanism for disruption of actin microfilament structure. Mol. Microbiol. 36:737748.

Wei, C.-F., Kvitko, B. H., Shimizu, R., Crabill, E., Alfano, J. R., Lin, N.C., Martin, G. B., Huang, H.-C., and Collmer, A. 2007. A Pseudomonas syringae pv. tomato DC3000 mutant lacking the type III effector HopQ1-1 is able to cause disease in the model plant Nicotiana benthamiana. Plant J. 51:32-46.

Xiang, T., Zong, N., Zou, Y., Wu, Y., Zhang, J., Xing, W., Li, Y., Tang, X., Zhu, L., Chai, J., and Zhou, J. M. 2008. Pseudomonas syringae effector AvrPto blocks innate immunity by targeting receptor kinases. Curr. Biol. 18:74-80

Xiao, F., He, P., Abramovitch, R. B., Dawson, J. E., Nicholson, L. K., Sheen, J., and Martin, G. B. 2007. The N-terminal region of Pseudomonas type III effector AvrPtoB elicits Pto-dependent immunity and has two distinct virulence determinants. Plant J. 52:595-614. 